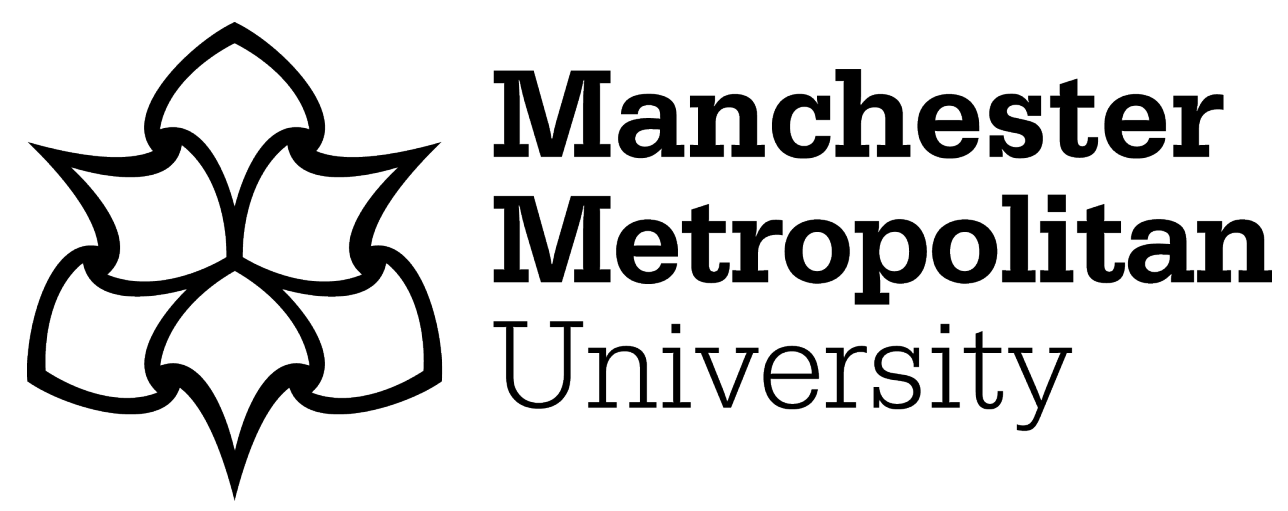

Slate, AJ, Whitehead, KA, Brownson, DAC and Banks, CE (2019) Microbial fuel cells: An overview of current technology. Renewable and Sustainable Energy Reviews, 101. pp. 60-81. ISSN 1364-0321

Downloaded from: https: //e-space.mmu.ac.uk/621924/

Version: Accepted Version

Publisher: Elsevier

DOI: https://doi.org/10.1016/j.rser.2018.09.044

Usage rights: Creative Commons: Attribution-Noncommercial-No Derivative Works 4.0

Please cite the published version 


\title{
Microbial Fuel Cells: An Overview of Current Technology
}

\author{
Anthony J. Slate, ${ }^{1,2,3}$ Kathryn A. Whitehead,,${ }^{1 *}$ Dale A. C. Brownson, ${ }^{1,3}$ \\ and Craig E. Banks ${ }^{1,3 *}$
}

${ }^{1}$ Faculty of Science and Engineering, Manchester Metropolitan University, Chester Street, Manchester M1 5GD, UK.

${ }^{2}$ Microbiology at Interfaces Group, Manchester Metropolitan University, Chester Street, Manchester M1 5GD, UK.

${ }^{3}$ Manchester Fuel Cell Innovation Centre, Manchester Metropolitan University, Chester Street, Manchester M1 5GD, UK.

Corresponding author *To whom correspondence should be addressed.

Email: c.banks@mmu.ac.uk; Tel: +44 (0)1612471196

Email: k.a.whitehead@mmu.ac.uk; Tel: +44 (0)1612471157 


\begin{abstract}
Research into alternative renewable energy generation is a priority, due to the everincreasing concern of climate change. Microbial fuel cells (MFCs) are one potential avenue to be explored, as a partial solution towards combating the over-reliance on fossil fuel based electricity. Limitations have slowed the advancement of MFC development, including low power generation, expensive electrode materials and the inability to scale up MFCs to industrially relevant capacities. However, utilisation of new advanced electrode-materials (i.e. 2D nanomaterials), has promise to advance the field of electromicrobiology. New electrode materials coupled with a more thorough understanding of the mechanisms in which electrogenic bacteria partake in electron transfer could dramatically increase power outputs, potentially reaching the upper extremities of theoretical limits. Continued research into both the electrochemistry and microbiology is of paramount importance in order to achieve industrial-scale development of MFCs. This review gives an overview of the current field and knowledge in regards to MFCs and discusses the known mechanisms underpinning MFC technology, which allows bacteria to facilitate in electron transfer processes. This review focusses specifically on enhancing the performance of MFCs, with the key intrinsic factor currently limiting power output from MFCs being the rate of electron transfer to/from the anode; the use of advanced carbon-based materials as electrode surfaces is discussed.
\end{abstract}

Keywords: Microbial Fuel Cells; Electromicrobiology; Microbiology; Electrochemistry; Graphene. 


\begin{tabular}{ll}
\hline Description & Identifier \\
\hline Adenosine Tri-Phosphate & ATP \\
Carbon Nanotubes & CNTs \\
Chemical Oxygen Demand & COD \\
Glassy Carbon Electrode & GCE \\
Hydrogen Evolution Reaction & HER \\
Microbial Fuel Cells & MFCs \\
Multiwall Carbon Nanotubes & MWCNTs \\
Nicotinamide Adenine Dinucleotide & NADH \\
Nicotinamide Adenine Dinucleotide Phosphate & NADPH \\
Normalised Energy Recovery & NER \\
Oxygen Reduction Reaction & ORR \\
Phosphate Buffer Solution & PBS \\
Proton Exchange Membrane & PEM \\
Scanning Electron Microscopy & SEM \\
Sediment Microbial Fuel Cell & SMFC \\
Single-Wall Carbon Nanotubes & SWCNTs \\
Three-Dimensional & $3 D$ \\
Transmission Electron Microscopy & TEM \\
Tricarboxylic Acid Cycle & TCA \\
Two-Dimensional & $2 D$ \\
\hline &
\end{tabular}




\section{Introduction}

Energy generation, storage and consumption are topics that are increasingly prevalent within modern research fields and are of global interest and importance [1,2]. Research into alternative renewable energy generation sources are increasing exponentially, with vast research showing promising results, in an abundance of areas including: solar [3], wind [4], tidal [5], geothermal [6] and biomass energy generation (Figure 1) [7, 8]. Currently no individual renewable energy source has the ability to compete with and replace the conventional fossil-fuel based energy generation approach, however, combining renewable energy sources such as, solar-wind hybrids and/or solar-hydrogen fuel cells may be alternative routes to be explored $[9,10]$.

One potential alternative energy source is the use of microbial fuel cells (MFCs). MFCs follow a similar concept to traditional fuel cells (Figure 2). However, MFCs utilise the bio-catalytic capabilities of viable microorganisms and are capable of using a range of organic fuel sources, by converting the energy stored in the chemical bonds, to generate an electrical current instead of relying for example, on the use of metal catalysts [1]. Microorganisms, such as bacteria, can generate electricity by utilising organic matter and biodegradable substrates such as wastewater, whilst also accomplishing biodegradation/treatment of biodegradable products, such as municipal wastewater $[1,11]$. Table 1 provides an overview of the current literature of MFCs. Clearly, significant attention has been given to MFCs cells due to their ambient operating conditions (e.g. utilisation at low temperatures) and a variety of biodegradable substrates as fuel. This review aims to highlight the current understanding of MFCs, whilst giving a thorough overview of the field. Particular emphasis is placed upon the fundamentals of MFC technologies, electrode materials, mechanism of electron transport and field standardisation. Further, this review focusses specifically on enhancing the performance of MFCs via the optimisation of specific parameters, with the hope of highlighting the main limiting factors and bringing them to the forefront of future investigations.

\subsection{History of MFCs}

The first recorded occurrence of electrochemical activity between bacterial/fungal (yeast) species and electrodes can be traced back to the early $20^{\text {th }}$ century, reported by Potter, where live cultures of Escherichia coli and Saccharomyces spp., produced electricity using platinum macro-electrodes in a battery type setup with sterile media [12]. This was later confirmed by Cohen in 1931, who reported a voltage of $35 \mathrm{~V}$ at a current of $0.2 \mathrm{~mA}$ from a 
stacked bacterial fuel cell system [13]. Although these publications are often referred to as the origin of electromicrobiology, it was not until 1963 when a National Aeronautics and Space Administration (NASA) space program demonstrated the opportunity to recycle and convert human waste to electricity during space flights [14-16]. In 1990, pioneering work from Habberman and Pommer first reported a long-term MFC. In this study, the MFC in question was employed in continuous service, for 5 years (i.e. from 1986), utilising municipal wastewater, without malfunction or maintenance [11]. Further, this study for the first time reported indirect electron transfer (a mechanism of electron transfer, which allows specific bacteria to donate electrons) via soluble mediators, the example in this study was sulphate/sulphide [11]. To the best of the authors' knowledge, this study was also the first time that the treatment of domestic wastewater was reported [11, 17]. In 1999, it was discovered that mediators were not an essential component within MFC configurations, this allowed MFCs to be developed without the need for expensive mediators [18-20]. Following this, an exponential increase in interest occurred within the field of electromicrobiology research, which now boasts over a thousand energy-generation-cells reported in the literature, and the first commercial prototypes are expected soon [21].

\subsection{Fundamental Bioelectricity Generation in MFCs}

The development of a bio-potential, due to the bacterial metabolic activity in the anodic compartment (i.e. reduction reactions, generating both electrons and protons), and electron acceptor conditions in the cathode (which are separated by a membrane), leads to the generation of bioelectricity in MFCs $[22,23]$. In the anodic compartment, the electrochemically active microorganisms can donate electrons to an anode, which are liberated by oxidising organic/inorganic waste (e.g. the fuel), thus producing a source of energy [1]. An example of an oxidation reaction that takes place by electrochemically active bacteria in the anodic compartment, using acetate as a fuel source can be summarised as [24]:

$$
\mathrm{CH}_{3} \mathrm{COO}^{-}+4 \mathrm{H}_{2} \mathrm{O} \rightarrow 2 \mathrm{HCO}_{3}^{-}+9 \mathrm{H}^{+}+8 e^{-}
$$

Electrochemically active microorganisms capable of donating electrons have been previously defined by Logan as exoelectrogens [25]. Other synonyms used throughout the literature include, anode respiring bacteria, [26] electrochemically active bacteria [27, 28] and electricigens [29, 30]. Microorganisms capable of accepting electrons have been termed, exoelectrotrophs $[31,32]$. Protons produced via the electrochemically active bacteria in the anode diffuse through a half-cell separator (e.g. proton exchange membrane (PEM)) into the cathodic compartment. In the cathodic compartment, oxygen is primarily used as the oxidant, 
due to its abundance and high reduction potential $[33,34]$. However, the oxygen reduction reaction (ORR), remains one of the contributing bottleneck factors which is inhibiting further optimisation and therefore improvement of MFC configurations, due to both high overpotentials and low kinetics observed $[33,35]$. Other studies have shown the application of metal oxidants in the cathodic compartment, examples include, copper, cadmium and chromium [35-40]. Once the protons have diffused through the PEM into the cathode they can combine with oxygen that is present, leading to the generation of water via the following oxygen reduction reaction (ORR), which can be summarised as [41, 42]:

$$
\mathrm{O}_{2}+4 \mathrm{H}^{+}+4 e^{-} \rightarrow 2 \mathrm{H}_{2} \mathrm{O}
$$

In order to be classified as an MFC, a device must be capable of having its fuel source, which is oxidised at the substrate-anode interface (e.g. wastewater), replenished either intermittently or continuously, otherwise the system is not referred to as a MFC, but rather, it is bio-battery [24]. The majority of MFC configurations are often utilised as anaerobic devices. This is due to the anaerobic conditions required by bacterial species' currently seen as the "gold standard" in regards to electron transfer properties e.g. Geobacter sulfurreducens [21].

MFCs are routinely operated as closed-system devices, where the anodic compartment is kept under anaerobic conditions. This is required in order to facilitate the growth of obligatory anaerobic bacteria capable of electron transfer, such as $G$.

sulfurreducens [21]. To date, fuel sources with bacteria that have been identified as being capable of partaking in electron transfer include wastewater, marine sediment soil, freshwater sediment, soil and activated sludge (Table 1) [43, 44]. Bacteria in such systems are able to produce electrons by oxidising substrates that are isolated in the anodic compartment. These electrons flow from the anode to the cathode (positive terminal) via an external circuit, this leads to the production of electricity due to the difference in potential coupled to the electron flow $[24,45]$. Protons that are produced at the anode are able to migrate through the solution and across the PEM [46]. PEMs are the most frequently used separators in MFCs due to their desirable properties such as, high conductivity to cations, selective permeability to protons, low internal resistance and the ability to undergo long periods of inactivity without having a detrimental effect on the MFC [47-49]. Once at the cathode, the electrons are able to combine with both protons and water to form oxygen. Currently, the maximum power densities that microorganisms are theorised to be capable of producing have not yet been reached. Theoretically, a single Escherichia coli cell that replicates twice every hour with a volume of $0.491 \mu \mathrm{m}^{3}$ has the potential to produce $c a .16,000 \mathrm{~kW} \mathrm{~m}^{-3}$ [50]. Depending on the energy gain 
by the bacteria and the loss of energy at the cathode, a voltage of between $0.3 \mathrm{~V}$ and $0.5 \mathrm{~V}$ is usually obtained when using energy sources (fuels) such as glucose and acetic acid [50]. The current produced from a MFC is dependent on the rate of substrate biodegradation, whilst the maximum theoretical cell voltage also known as the electromotive force, is dependent on the Gibbs free energy (a thermodynamic quantity equal to the enthalpy of a system, plus the temperature and entropy) of the overall reaction [51]. This can be calculated as the difference between the standard reduction potentials of the specific anodic substrate and the cathodic oxidant $[17,24,52]$. However, a MFCs electromotive force does not factor in internal losses (i.e. resistance) and therefore experimental values are subsequently always significantly lower than theoretically obtained values $[24,51]$.

Most modern MFC technologies developed thus far utilise wastewater as a fuel source, working on the basis of recovering energy via the biodegradation of organic-rich waste [1]. The ability to generate electricity from wastewater could play a pivotal role in the production of renewable energy. In 2012, it was reported that $5 \%$ of the USA's total energy consumption was used to facilitate water and wastewater treatment facilities [53]. However, for the adequate treatment of wastewater (to relevant regulations and standards), issues surrounding the effluent quality of MFC treated wastewater are yet to be addressed sufficiently [54]. The treatment of wastewater by MFCs alone, may not be a viable option due to stringent effluent quality requirements [54]. Therefore, the addition of other steps such as MFCs integrated with membrane technology and conventional treatment technology (post MFC stage) may also be required [54-56]. MFCs offer a significant advantage over other renewable energy sources, as they can be applied towards wastewater treatment. Another advantage of MFC technologies is it is less dependent in comparison to other renewable energy technologies (i.e. solar and wind) upon geographical location and seasonal change [17]. Ye et al (2016) have previously demonstrated a sediment MFC which was capable of power output in temperatures ranging from $4{ }^{\circ} \mathrm{C}$ to $35^{\circ} \mathrm{C}$ [57]. Further, MFCs can generate hydrogen from the fermentation of sugars in wastewaters, which can then in turn be utilised as a fuel source in other renewable energy technologies [29]. Oh et al (2005), investigated hydrogen production from food processing wastewaters in conjunction with electricity production [58].

The model bacterial species currently used in MFCs are iron-reducing species such as Shewanella spp., and Geobacter spp [25]. These bacteria have the ability to degrade organic matter for nutrient cycling, for example iron oxides found in both soil and sediments [59]. 
Graphite macro-electrodes (unpolished; grade G10, geometry: sticks) have been used to grow such bacterial species as G. sulfurreducens, where acetate was used as an electron donor (2 $\mathrm{mM})[60]$.

\subsection{Structural Configurations}

The structural configuration of MFCs varies considerably, ranging from single and two-chamber configurations and with or without the utilisation of a PEM [46, 61, 62]. Figure 2 provides a schematic presentation of a typically utilised MFC configuration which comprises of two-chambers, an anodic chamber and a cathodic chamber which are connected by a half-cell separator, with the most commonly utilised separators being, PEM's, salt bridges and ceramics $[41,63,64]$. This allows protons to move freely to the cathode due to a potential gradient, whilst inhibiting the diffusion of oxygen (or the electron acceptor utilised in the cathodic compartment) to the anode where it can have a potential detrimental effect on the bacteria present.

The structural design of the compartments can vary dramatically in order to enhance power outputs of MFCs. Two-compartment MFCs are typically utilised with a defined medium (such as glucose or acetate) and ran in batch mode. MFCs can also be operated in a continuous mode) and are currently used in laboratories to optimise MFC power outputs [1]. Examples of two-compartment MFC designs include, conventional rectangular shaped MFCs, [1, 65, 66] cylindrical shaped MFCs, [67-70] miniature MFCs, [71-73] up-flow mode configurations $[74,75]$ and flat plate $\operatorname{MFCs}[76,77]$.

Miniature MFCs are receiving considerable attention in both fundamental and applied studies, due to their intrinsic advantages [71]. Miniature MFCs are capable of generating electricity at the millilitre to microlitre scale [71]. One example of a miniaturised MFC has been demonstrated by Mink et al (2014) [78]. In this study, a MFC was fabricated with a graphene anode and an air cathode, with a working volume of $25 \mu \mathrm{L}$, whilst utilising human saliva as a fuel source [78]. This configuration produced a maximum current density of 1190 $\mathrm{A} \mathrm{m}^{-3}$, this was higher than any previous air-cathode micro-sized MFC [78]. Interestingly, in this study, the utilisation of graphene resulted in a 40 times increase in power than that of the carbon cloth control [78]. These findings could potentially result in saliva-powered appliances, utilising MFC technology for both Lab-on-a-Chip and point-of-care diagnostic devices [78]. Further, miniature MFC configurations have shown potential promise as power sources for long-term underwater or littoral autonomous sensors, as MFCs can scavenge nutrients from the environment allowing for the electrogenic biofilm to be sustained at the 
anode $[1,79]$. Miniature MFC configurations would be particularly beneficial in isolated regions as Ringeisen et al have shown that the power output of MFCs is more sensitive to diffusion distance through the PEM, rather than electrode size, thus allowing for more effective power outputs in miniaturised configurations [80].

Up-flow mode MFC configurations have received vast attention, due to their increased suitability for application in wastewater treatment, due to their relative ease to scale-up to industrially relevant sizes [1]. Min and Logan developed the flat plate MFC, in order to replicate the parameters utilised in traditional hydrogen fuel cells, where the electrodes are usually combined into a single strip separated by a PEM; thus allowing the electrodes to be kept in close proximity to enhance proton conduction between the two electrodes [76]. However, in the case of MFCs, PEMs such as Nafion are often utilised which are permeable to oxygen, this could have a detrimental effect on obligate anaerobes if used as the bacteria of choice in the anodic compartment [76]. Therefore this prototype was tested to evaluate if the design was more beneficial than the risk of oxygen permeation to the anode [76]. The results from this flat plate MFC configuration showed a maximum power density of $72 \mathrm{~mW} \mathrm{~m}^{-2}$ when domestic waste water was utilised as the fuel source, this represents a 2.8 times increase in power output when compared to that of a single chambered MFC design, tested by the same research group [76]. Other structural configurations have been utilised throughout MFC technologies, and designs such as tubular configurations have been developed and shown to be advantageous towards increasing power outputs [81, 82].

Sediment microbial fuel cells (SMFCs) have been intensively explored for energy generation from natural sediment, with recent focus in particular on their application for wastewater treatment [83]. SMFCs produce electrical current from the organic matter content of sediments using bacterial metabolism. SMFCs differ from other MFCs due to their essentially complete anoxic conditions at the anode and their membrane-less structure, where the sediment/water interface acts as the membrane [84, 85]. However, SMFCs have been criticised, as such set ups are unlikely to generate considerable amounts of electrical energy in order to compete with other energy sources. This is due to their reported limitations, such as large internal resistance and issues arising from scaling up, as increasing electrode size can result in a decrease in power density $[83,86]$. Despite this, research into SMFCs has intensified recently due to their realised dual functionalities allowing for electricity generation and wastewater treatment via the removal of specific contaminations [83]. A study in 1989, using a non-corrosive stainless steel mesh that was plated with platinum black and 
utilised as the anode, produced a current density of $\left(c a .60 \mu \mathrm{A} \mathrm{cm}^{-2}\right)$ with Enterobacter aerogenes [87].

Due to their complex architectural designs, it is difficult to scale up two chambered MFC configurations [1]. Single chamber configurations offer simpler designs and eliminate the need for a cathodic chamber, as the cathode is exposed directly to the air [1]. This allows for greater financial efficiency, due to the lack of requirement for a cathodic compartment and electron acceptors. Note, because passive oxygen transfer to the cathode does not require air sparging of the catholyte, which is an energy intensive process, this further reduces financial expenditure [88]. The protons produced in the anodic compartment are transferred from the anolyte solution to the porous air-cathode [88]. The first reported single chamber MFC was developed in 2003 by Park and Zeikus [89]. This comprised of a rubber bunged bottle with a centrally-inserted anode and a window-mounted cathode which contained an internal proton-permeable porcelain layer, when sewage sludge was used as the biocatalyst, a maximum power density of $788 \mathrm{~mW} \mathrm{~m}^{-2}$ was obtained [89].

In order to attempt to scale up MFC technologies to an industrially-relevant level, it has been previously demonstrated that a miniaturisation and multiplication approach is one viable route to scale up power output, as opposed to merely increasing the reactor size [9093]. In light of this, stacked MFCs have been developed. Stacked MFCs allow multiple, individual MFCs to be connected in series or parallel allowing power outputs produced to be enhanced [94]. Aelterman et al, connected six individual continuous MFC units and produced a maximum hourly average of $258 \mathrm{~W} \mathrm{~m}^{-3}$, whilst utilising a hexacyanoferrate cathode and identical graphite granule electrodes (type00514, diameter between 1.5 and $5 \mathrm{~mm}$, Le Carbone, Belgium) [94]. However, Oh and Logan revealed that when multiple MFCs are stacked together a charge reversal can occur and this can result in a reverse in polarity for one or more of the cells and a reduction in power outputs [95]. Voltage reversal generally occurs when one or more cells in a stacked MFC configuration experiences a more extreme condition (with one example being fuel starvation) compared to the other cells [95]. More specifically, this phenomenon occurs when excessive current is drawn from the fuel cell, at a higher rate than its fuel delivery can support, subsequently this leads to an increase in the anode potential and thus voltage reversal occurs [94].

Other conditions that can result in voltage reversal and therefore impair power outputs include, lack of oxygen at the cathode, impedance differences, lack of a catalyst and insufficient fuel [95]. However, a number of studies have demonstrated MFC stacks that have overcome this issue [95-97]. One example of this is by short-circuiting a cell demonstrating 
voltage reversal, researchers have used diodes connected in parallel in a hydrogen fuel cell due to their low ohmic resistance, therefore when one or more of the cells are defective, the MFC can automatically short-circuit [95]. Avoiding fuel starvation i.e. ensuring there is sufficient substrate at the anode and oxygen at the cathode (for air-cathodes) has also been shown to reduce the possibility of voltage reversal [95]. Further, operating the MFC configuration at lower current densities has also shown to inhibit voltage reversal [95].

One material with the potential of advancing the field of MFCs are ceramics [98, 99]. Research thus far demonstrates that when this material is used as a half cell separator, results obtained are comparable to more conventional ion exchange membranes, with the added benefit of being considerably less expensive [98]. The first demonstration of ceramic materials utilised in a MFC configuration was reported in 2003 by Park and Zeikus [89]. In this study, a proton permeable porcelain separator was employed and positioned between graphite electrodes [89]. The graphite electrodes contained surface bound mediators, with the anode containing $\mathrm{Mn}^{4+}$ and the cathode $\mathrm{Fe}^{3+}$ [89]. With E. coli as the biocatalyst the maximum current density and power density were, $1,750 \mathrm{~mA} \mathrm{~m}^{-2}$ and $788 \mathrm{~mW} \mathrm{~m}^{-2}$, respectively [89]. The use of ceramic membranes has allowed for MFCs to be used in field trials, with one example being by Ieropoulos et al (2016) [100]. In this study, the application of ceramic membranes allowed the cost of the structural materials to be decreased to as low as 4.14 GBP per $\mathrm{m}^{2}$ [101]. This is directly comparable with conventional cation exchange membrane, which in 2016 cost 79.17 GBP per $\mathrm{m}^{2}$ [101].

In order to increase and optimise the efficiency of MFCs utilising ceramic materials, it is stipulated that varying the ceramic type (with one example being earthenware), the porosity of the clay and the thickness of said ceramic could lead to an increase in power output [98]. Ceramic electrodes have also been developed, as well as ceramic chassis/housing units, this is beneficial, as it would allow the manufacturing process to be simplified, as the entire unit could be manufactured and kilned simultaneously $[98,102]$. Throughout the literature there are many studies, which describe the coating of ceramics with conductive materials [98]. An example of this has been demonstrated by Thorne et al, in this study porous ceramic electrodes were developed by coating macroporous titanium dioxide ceramics with a thin layer of fluorine-doped tin oxide, by chemical vapour deposition [103]. The power density obtained by the modified ceramic electrodes was around 16 times higher than the best performing carbon anode [103].

\subsection{Limiting Factors}


The limiting factors of MFCs are reported to be high-associated costs (most notably due to electrode materials and the use of PEMs), low energy outputs and limited life spans; the key intrinsic factor currently limiting the power output of MFC technologies is the rate of electron transfer to the anode and the electrochemical properties of the material [104]. Further, the PEM has been shown to be the main source of internal resistance $\left(R_{\text {in }}\right)$ of MFCs $[23,28,105]$. In light of these limiting factors, MFCs are currently unable to attain their theoretical power outputs and therefore implementation of this technology into industry is not yet feasible.

The overall efficiency and performance of a MFC can be effected by a vast array of factors as depicted in Figure 3. Other performance-limiting factors have arisen whilst trying to enhance the performance of MFC for industrial and social applications, these include biofouling (leading to electrode surface blockage and ultimately a reduction in surface area), catalyst inactivation (if present) and excessive biofilm growth - possibly leading to the production of non-conductive debris (Figure 3) [106]. The production of non-conductive debris such as polymeric substances and/or dead cells, can isolate the electrochemically active biofilm from the electrode surface or with more porous electrodes become entrapped in the $3 \mathrm{D}$ architecture; leading to a potential reduction in available surface area and ultimately a reduction in current generation [106-108]. A study conducted in 2017, used cell viability counts and field emission scanning electron microscopy analysis to show that an increase in high polarisation resistance correlated with the formation of a dead layer of cells [108]. Further, this study also revealed that the use of ultrasonic treatment was a verified method of controlling biofilm thickness and enhanced cell viability, maintaining stable power generation [108].

There have been other biofilm related factors that are thought to contribute to the performance of a MFC. In a study conducted by Sun et al (2015), it was revealed that when the predominant bacteria in an MFC set-up was Geobacter anodireducens, a two-layered biofilm developed over time, with an inner dead core and an outer layer of live cells [109]. Results suggest that the outer layer was responsible for current generation and the dead innerlayer continued as an electrically conductive matrix [109]. It could be speculated that this continued electrochemical activity could be dependent upon the mechanism of electron transfer, for example Geobacter spp., are well known for their electrochemical activity due to nanowires - which may still have a viable connection to the electrode surface, even through the non-conductive debris. 
Other attributing factors which can have a detrimental effect on both the power outputs and the efficacy of a MFC is the inactivation of electro-catalysts (if present) and the crossover of organic compounds or electron acceptors from the anode to the cathode (and vice versa). The crossover of electron acceptors from the cathodic compartment into the anode has been shown in a previous study to disrupt biofilm formation and lead to biofilm inactivation, which can considerably decrease MFC performance, due to the flow of internal currents and the formation of mixed potentials (i.e. a system that is short-circuited) [110, $111]$.

\subsection{Optimisation of MFC Power Outputs}

The power output obtained via MFC technologies can be improved by a number of ways (Table 2):

Table 2. Possible mechanisms by which to improve the power output.

\begin{tabular}{lc}
\hline Mechanism & Ref \\
\hline Architectural design of the MFC setup & {$[112]$} \\
Alternative electrode material selection & {$[113]$} \\
Improvement of the cathodes (viable alternatives to platinum) & {$[114]$} \\
Closer-spaced electrodes (leading to a decrease in ohmic resistance) & {$[115]$} \\
Solution selection (allowing for increased conductivity) & {$[116]$} \\
Addition of substrates (more acquiescent to energy production) & {$[21]$} \\
Enhancement of appropriate fuel source & {$[117,118]$} \\
Introduction of a magnetic field to MFC configurations & {$[119,120]$}
\end{tabular}

The introduction of a magnetic field to living microorganisms produces a phenomenon known as the magnetic biological effect [121]. This effect has been shown to induce a series of biological reactions in microorganisms, for example, magnetic fields effect DNA, enzymes and organisational structure of biofilms, which in turn can lead to an alteration in the metabolism of the microorganism $[122,123]$. The introduction of a high static magnetic field inhibits the physiological processes in microorganisms, whilst the use of lower static magnetic fields promotes microbial activity/growth [124]. In one study, the application of a $100 \mathrm{mT}$ magnetic field increased electricity production of Shewanellainoculated MFCs, leading to an increase in the maximum voltage by $20 \%-27 \%$ [125]. This 
improvement in electricity production has mainly been attributed to enhanced bioelectrochemical activity, possibly due to the induction of oxidative stress mechanisms $[124,125]$.

The introduction of a magnetic field has also been shown to affect the bioelectrocatalytic transformations of several enzymes on the electrode surface, resulting in accelerated electron transfer at the electrode-solution interface [126-128]. Yin et al, reported that the utilisation of magnetic fields (in the range of $0 \mathrm{mT}, 100 \mathrm{mT}, 200 \mathrm{mT}$ and $300 \mathrm{mT}$ ) led to a decrease in start-up periods of the MFCs, with the $100 \mathrm{mT}$ needing the least amount of time (7 days) to obtain a stable voltage output [119]. Further, the maximum power density reported, was produced by the MFC under a $200 \mathrm{mT}$ magnetic field $\left(1.56 \mathrm{~W} \mathrm{~m}^{-2}\right)$ compared to the control MFC with no magnetic field $\left(1.19 \mathrm{~mW} \mathrm{~m}^{-2}\right)$ [119]. However, the MFC subjected to a $300 \mathrm{mT}$ magnetic field, produced a power density of $0.99 \mathrm{~W} \mathrm{~m}^{-2}$. Therefore, it was suggested that there is an optimal intensity magnetic field range, and this could be dependent on the microorganisms utilised in MFC configurations [119]. Thus, it may be noted, that the influence of the magnetic field on the cathode of an MFC setup (due to its effect on the electrical behaviour towards the ORR) needs to be explored comprehensively in order to optimise this method for application within MFCs [119, 129, 130].

Other studies have reported that the utilisation of low static magnetic fields $(\leq 220$ $\mathrm{mT}$ ) improved the cell performance of a MFC demonstrating that the MFC under a $220 \mathrm{mT}$ magnetic field resulted in the best output voltage $(756 \mathrm{mV})$, compared to the control MFC which had no magnetic field $(360.1 \mathrm{mV})$. The use of higher magnetic fields with MFCs, such as $360 \mathrm{mT}$ have been shown to exhibit negative effects upon cell performance. This may lead to a decrease in biomass, lowered maximum voltage $(171.8 \mathrm{mV})$ and lower pollutant removal in the case of residual ammonia nitrogen $\left(84.6 \pm 0.5 \mathrm{mg} \mathrm{L}^{-1}\right)$ [120]. It is apparent that before magnetic fields can be used to optimise MFCs, comprehensive studies must be undertaken in order to optimise this technique.

The use of catalysts and electron acceptors in MFC configurations is non-essential and their use is often expensive due to the constant need to replenish exhausted materials. In order to avoid expensive costs associated with the use of catalysts/electron acceptors in the cathodic compartment, research interest is currently directed to replacing these materials with microorganisms, known as biocathodes, which can assist and improve cathodic reactions [131]. Both aerobic and anaerobic biocathodes have been explored, this is of paramount importance depending on the terminal electron acceptor adopted in the cathode. One example of an aerobic biocathode is Thiobacillus ferrooxidans, and this bacteria has been shown to 
regenerate ferric ions, which have been utilised as electron mediators in the cathodic compartment [131]. An example of an anaerobic biocathode is Geobacter metallireducens which has the ability to oxidise ammonia and reduce nitrate (to nitrogen), leading to denitrification in an MFC configuration [131].

\section{Electrode Materials}

One area which could potentially be explored in order to optimise power output from MFCs, are the electrode materials themselves. In order for a material to be effective as an electrode, it should have a number of properties. It should ideally be economical and exhibit beneficial electrochemical properties (i.e. favourable electron transfer) whilst being mechanically stable, in conjunction with a large surface area, giving rise to large current densities.

\subsection{Materials}

The electrode material is a major constituent of a MFC, determining both the performance and the cost [132]. One of the key areas of current research in electrochemistry is to develop new materials in order to replace platinum [133]. The urgent need to replace platinum is due to the increased global demand as this is a crucial resource within a plethora of industries, with major applications in catalysts, electronics and electrodes [133]. This, combined with an inadequate supply (approximate annual global supply is about $200 \mathrm{Mg}$ (metric ton)), has led to a price surge in platinum making it extremely expensive [133, 134]. Platinum may not be suitable as an electrode material for application within MFCs, as this metal has shown antimicrobial properties which lead to the inhibition of E. coli division, due to products produced (cisplatin) from a platinum electrode during electrolysis [135]. In light of this, carbon materials and non-corrosive metals are currently the most widely used base electrode materials in MFC configurations, as these materials meet the above requirements (Table 1) [136]. The selection and optimisation of suitable electrode materials is essential in order to increase power outputs from MFCs, as the selected material has been shown to have a significant influence on the release, transfer and acceptance of electrons between the electrodes and the bacteria $[132,137,138]$.

\subsection{Electrode Topography}

Electrodes utilised in MFCs not only function as conductors, as with traditional fuel cells, but the anode material also acts as a support for bacterial biofilms and therefore must be 
biocompatible with the bacterial cells present. A high surface area is desirable, and a relatively rough surface is thought to be an ideal surface property in a MFC configuration, as it helps with the retention of the bacteria to the surface [136]. Surface roughness/area of the electrode materials has also been shown to play an important role in the generation of electricity [139]. Walter et al, demonstrated that increasing the total anodic surface area, within a fixed volume chamber resulted in an increase in volumetric power density of the MFC [139]. Ye et al, demonstrated that when two glassy carbon plates were polished to uniform roughness in the order of magnitude of 10's to 100's of nanometres, after 275 hours of experimentation, the (relatively) rougher electrode surface produced higher power densities than its smoother counterpart. Surface roughness is a vital parameter that needs appropriate consideration when selecting electrode materials [140].

\subsection{Oxygen Reduction Reactions}

Another potential avenue to explore when trying to enhance power density outputs of the MFCs is improving the oxygen reduction reaction (ORR). This takes place in the cathode (compared to the hydrogen evolution reaction (HER) in microbial electrolysis cells (MECs)) [141]. One way to optimise electricity output is to utilise electro-catalysts or electrode materials that exhibit enhanced electrochemical properties, such as boron nitride and molybdenum disulphide. These materials possess the ability to reduce the over potential of the key electrochemical reaction, leading to a marked improvement in efficiency [49, 142144].

Feng et al, reported that a nitrogen-doped graphene catalyst (of 2-8 layers) gave rise to the oxygen reduction reaction at facile potentials, comparable to that of a platinum catalyst, therefore in a MFC configuration this could give rise to beneficial outputs of the MFC [145]. The advantages of nitrogen-doped graphene include being less expensive than platinum with improved long-term operational stability in comparison to commercial platinum electrodes as measured within alkaline electrolytes [145, 146].

Another example of utilising catalysts to improve the ORR in MFCs has been demonstrated by Li et al, [147] using iron and nitrogen functionalised graphene sheets (Fe-N$\mathrm{G}, c a .>2 \mu \mathrm{m}$ ), which were more disordered than pristine graphene. The sheets were synthesised and utilised as a non-precious metal catalyst for use within a single-chamber aircathode MFC. This MFC comprised of a cylindrical anode chamber $(5 \mathrm{~cm}$ diameter and an effective volume of $40 \mathrm{~mL}$ ), a cation exchange membrane and carbon felt electrodes [147]. The catalysed cathode was placed at a distance of $1 \mathrm{~cm}$ from the anode, with its waterproof 
layer facing towards air [147]. It was found that when used with MFCs, the Fe-N-G catalyst obtained the highest power density $\left(1149.8 \mathrm{~mW} \mathrm{~m}^{-2}\right)$ in comparison to a pristine monolayer graphene catalyst control, $\left(561.1 \mathrm{~mW} \mathrm{~m}^{-2}\right)$ and a commercial $\mathrm{Pt} / \mathrm{C}$ catalyst $\left(109 \mathrm{~mW} \mathrm{~m}^{-2}\right)$ [147].

\subsection{Capacitive Layers}

Capacitive bioanodes have been trialled in MFC configurations [148-151]. In one study by Deeke et al, (2012), a capacitive layer was coated onto a current collector (plain graphite plate electrode). This consisted of a mixture of activated carbon and a polymer solution, consisting of $\mathrm{N}$-methyl-2-pyrrolidone and poly(vinylidene fluoride), this capacitive bioanode was compared against a plain graphite plate electrode. The cathode utilised in both MFCs was a plain graphite electrode plate [148]. During polarization curves, the capacitive bioanode maximum current density was $1.02 \pm 0.04 \mathrm{~A} \mathrm{~m}^{-2}$, whilst the control electrode reached a maximum of $0.79 \pm 0.003 \mathrm{~A} \mathrm{~m}^{-2}$ [148]. During charge-discharge experiments (with 5 minutes charging and 20 minutes discharging) the capacitive electrode was able to store a total of $22,831 \mathrm{C} \mathrm{m}^{-2}$ compared to the control (non-capacitive) electrode $12,195 \mathrm{C} \mathrm{m}^{-2}$. Furthermore, the capacitive electrode was capable of recovering $52.9 \%$ more charge during each charge-discharge experiment [148]. This indicated that the application of capacitive electrodes in MFCs allowed for simultaneous production and storage of electricity generated [148].

Research from the same group, showed that variation in the thickness of the capacitive layer had an effect on the efficacy of the electrode [152]. Of the electrodes tested with capacitive layers of, $0.2 \mathrm{~mm}, 0.5 \mathrm{~mm}$ and $1.5 \mathrm{~mm}$, the electrode with a capacitive layer of $0.2 \mathrm{~mm}$ out-performed the other electrodes in all studies. This electrode produced a maximum current density of $2.53 \mathrm{~A} \mathrm{~m}^{-2}$ during polarization curves, and during chargedischarge experiments stored a cumulative total charge of $96,013 \mathrm{~cm}^{-2}$ [152]. This was the first study to identify a parameter that can determine the performance of a MFC with a capacitor [152].

\subsection{Carbon Based Electrodes}

The use of carbon-based electrodes has long been established and has led to the production of vast amounts of analytical and industrial applications, due to carbon's high efficacy in heterogeneous electron transfer kinetics. Figure 4 offers a schematic detailing the 
structure of five allotropes of carbon [153]. Since the discovery of graphene, there has been a rapid increase in research interest towards utilising this and other novel 2D-nanomaterials, especially in the field of electrochemistry. Nanomaterials, such as carbon nanomaterials, possess many reported beneficial properties, which potentially make them ideal for electrode materials for use within MFCs. Such properties include a large surface area, enhanced electron transfer and promotion of the adsorption of molecules [154]. As microbial growth on the surface of metal anodes can accelerate the corrosion of metals in aqueous solutions, carbon-based electrodes are currently the material of choice for application with MFCs [155, 156]. A variety of carbon-based electrode materials have been trialled for use within MFC setups; these include graphite rods [46], carbon felts [157], carbon cloths [136] and carbon meshes [158].

\subsubsection{Carbon Cloth and Felt}

Carbon cloth has traditionally been one of the electrode materials of choice for use with MFCs due to its reported useful conductivity, stability, commercial availability and relatively inexpensive cost, in comparison to other carbon-based electrode materials. [88, 159] Carbon cloth comprises long individual carbon fibres, between $5 \mu \mathrm{m}$ to $7 \mu \mathrm{m}$ in diameter and is produced via the thermal decomposition of acrylic. These individual fibres are joined together as a bundle and are then weaved together to produce the carbon cloth $[160]$.

Carbon felt has also been utilised as an electrode material in MFCs. One study has compared the efficacy of carbon felt anodes, using bacteria isolated from sludge from a domestic wastewater plant. The results showed that under anaerobic conditions, a maximum power density of $7.07 \pm 0.45 \mathrm{~mW} \mathrm{~m}^{-2}$ was produced [161]. One study, which compared the electrochemical performance of 2D carbon cloth against 3D carbon felt (with spaces between the carbon fibres ranging from $c a .20 \mu \mathrm{m}$ to $200 \mu \mathrm{m}$ ), showed that the $2 \mathrm{D}$ carbon cloth enhanced the retention of bacteria. A $39.3 \%$ microbial volume ratio was demonstrated as opposed to the carbon felt, where bacterial retention was only $16.3 \%$ [107]. Denaturing gradient gel electrophoresis analysis determined that Delftia acidovorans, Citrobacter freundii and Ochrobactrum intermedium were isolated from the sludge and that these bacterial species may be potential electrogenic bacterial species [161]. Further, electrochemical analysis of the 2D and 3D carbon cloths showed that the 2D carbon cloth resulted in similar current densities to that of the $3 \mathrm{D}$ carbon felt, around $3.5 \mathrm{~A} \mathrm{~m}^{-2}$ [107]. This work demonstrated that 2D carbon cloth had promising potential as an electrode material for 
MFCs, offering a large specific surface area reported to be $\sim 2500 \mathrm{~m}^{2} \mathrm{~g}^{-1}$. Further, there was an increased biocompatibility when compared to the more traditional 3D porous carbon felts [162].

\subsubsection{Limitations of Carbon Cloth and Felt}

There are some limitations of the 3D carbon felt electrode, which were not present in the $2 \mathrm{D}$ carbon cloth, such as the clogging of pores. The clogging of pores in $3 \mathrm{D}$ porous carbon materials by the entrapment of bacterial cells can ultimately result in cell death. This may lead to a significant reduction of the active electrochemical reaction surface area, as well as a reduction in viable bacteria, thus reducing power outputs [17]. However, limitations have been associated with the use of 2D carbon cloth as an electrode material in MFCs, for example there is a poor reaction start-up [163]. This is often attributed to oxygen crossover from the cathode to the anode which can lead to the inhibition of current production by exoelectrogenic bacteria [163]. Recent research has resolved this problem by using a phosphate buffer to increase the solution conductivity. Further, pre-treating carbon cloth anodes with ammonia gas, was shown to increase the surface charge of the carbon cloths, by increasing the amount of amide groups on the surface [164]. The ammonia treatment of the carbon cloth was shown to increase power production by $48 \%$ and reduce start-up time by 50 $\%[164]$.

\subsubsection{Graphite}

Graphite has exceptional electrochemical properties, whilst the biocompatibility of graphite has been determined using scanning electron microscopy (SEM), as an abundance of a monoculture biofilm (E. coli) can be seen, adhered to a graphitic electrode surface (Figure 4). A study carried out by Chaudhuri and Lovley, demonstrated that increasing the graphite surface area available for microbial colonisation increased power outputs [165]. This was also demonstrated, when a two chambered MFC was utilised using a pure culture of Rhodoferax ferrireducens (anaerobic conditions for the anodic compartment), with excessive amounts of glucose $(10 \mathrm{mM})$ to act as an electron donor. Graphite felt electrodes (with a higher surface area) were compared against graphite rods and a threefold increase in current was produced $\left(0.57 \mathrm{~mA} \mathrm{~m}^{-2} ; 620 \mathrm{mV}\right)$ [165]. The study also compared porous graphite foam electrodes against the graphite rods. It was demonstrated that even though the geometric surface area was the same, the porous graphite foam produced a 2.4 fold increase in current 
(74 $\left.\mathrm{mA} \mathrm{m} \mathrm{m}^{-2} ; 445 \mathrm{mV}\right)$, which was attributed to the higher concentrations of cells which were able to adhere to the graphite foam electrodes [165].

\subsubsection{Graphene}

An example of a new research direction that has the potential to overcome some of the aforementioned issues would be the use of 2D-nanomaterials, such as graphene, as an electrode material/surface coating. Graphene, a two-dimensional (2D) monolayer lattice of $\mathrm{sp}^{2}$ hybridised carbon atoms, has attracted a plethora of interest in both the scientific and technological communities due to its reported unique properties [166]. Such properties include high physical strength [167], high electron mobility/conductivity at room temperature $\left(2.5 \times 10^{5} \mathrm{~cm}^{2} \mathrm{~V}^{-1} \mathrm{~s}^{-1}\right)$ [168] and a theoretical surface area estimated at $2630 \mathrm{~m}^{2} \mathrm{~g}^{-1}$ [169]. Graphene is also able to sustain extremely high densities of current (reported as one million times higher than copper) [170]. Such properties are ideal for efficient and effective electron transfer, making graphene a prime candidate for use as an electrode material within MFCs.

Graphene has previously been used as the anode material of an MFC with a pure culture of $E$. coli and delivered a maximum power density of $2668 \mathrm{~m} \mathrm{Wm}^{-2}$, which was 18 and 17 times larger than the stainless steel mesh and polytetrafluoroethylene modified electrodes, respectively [171]. Xiao et al, determined the difference between two types of graphene with varying, multilayer morphology $(c a .50 \mu \mathrm{m}-100 \mu \mathrm{m})$. These graphene sheets were more defective than pristine graphene due to the synthesis method utilised. This involved the thermal annealing of graphene oxide via the Hummers' synthesis, and crumpled graphene particles $(c a .0 .2 \mu \mathrm{m}-5.0 \mu \mathrm{m})$ produced via an aerosol-assisted capillary compression process $[172,173]$. These varying graphene morphologies were coated onto carbon cloth electrodes (loading rate: $\sim 5 \mathrm{mg} \mathrm{cm}^{-2}$ ) and tested to determine if the difference in surface area/surface roughness had a direct effect on the power density produced by the MFCs [172]. The results showed that modification of the graphene morphology from graphene sheets to crumpled graphene particles led to an increase in both surface area and the power density $\left(3.6 \mathrm{~W} \mathrm{~m}^{-3}\right)$. This was twice that of the activated carbon modified electrode $\left(1.7 \mathrm{~W} \mathrm{~m}^{-3}\right)$ [172]. Figure 5 offers an insight into this modification of graphene electrode morphology, showing how by increasing the surface area, an increase in the power density may be achieved.

The highest recorded power density produced to date, $5.61 \mathrm{~W} \mathrm{~m}^{-2} / 11220 \mathrm{~W} \mathrm{~m}^{-3}$, was achieved using a 3D multilayer graphene macroporous scaffold anode. The power density produced a 3.3 fold increase when compared to its planar single-layer 2D control counterparts 
[174]. Ren et al, demonstrated the ability to produce highly effective MFCs whilst utilising advanced 2D nanomaterials, such as graphene, as the anode/cathode material (Figure 6 and 7) [174]. It should be noted that the 2D nanomaterials must be correctly analysed and characterised for application as MFC electrodes. Raman spectroscopy is a powerful tool which can be used to effectively identify and characterise the number of layers of graphenebased electrode materials [175]. One of the challenges in the advancement of MFCs for industrial/social end-point applications (e.g. wastewater treatment) is both the cost and the reliability. Unfortunately, the production of 2D-nanomaterials such as graphene is unsustainable for this application, however it is expected that as more research is invested into the area of nanomaterials, the production costs will decrease significantly [176].

\subsubsection{Carbon Nanotubes}

Carbon nanotubes (CNTs) are another allotrope of carbon, where the carbon atoms are arranged in hexagons, like graphite. However, unlike graphite, the structure of CNTs consist of enrolled tubular graphene in the configuration labelled armchair. This is where the hexagons are orientated parallel to the axis of the nanotube arranged as a seamless cylinder $[174,177,178]$. CNTs can consist of one or more layers of graphene, which can then be denoted as either single-wall, (SWCNT), or multiwall, (MWCNT), with either open or closed ends [179]. CNTs have demonstrated excellent electrochemical activity due to a variety of factors. These include, their edge plane site/defects to basal plane ratio, chirality, relative size to surface area ratio and nanometre-sized diameter and micrometre-sized length, (where the length of the CNT exceeds the width ratio by one thousand times) [179-181]. SWCNTs and MWCNTs typically have diameters of $0.8 \mathrm{~nm}$ to $2 \mathrm{~nm}$ and $5 \mathrm{~nm}$ to $20 \mathrm{~nm}$, respectively, although the diameter of MWCNT may exceed $100 \mathrm{~nm}$ and have a hollow geometry [179, $180]$.

CNTs have demonstrated enhanced electrochemical performance, in comparison to more traditional electrodes when utilised within MFC technologies [182]. Cyclic voltammetry was utilised to compare the electrochemical activity of a glassy carbon electrode (GCE), with its surface modified with MWCNTs, using Shewanella oneidensis [182]. The results found that the use of CNTs raised the current density to $9.70 \pm \mu \mathrm{A} \mathrm{cm}^{-2}, 82$ times greater than the GCE control [182]. This was further confirmed when CNT mat-modified aircathodes produced a maximum power density of $329 \mathrm{~mW} \mathrm{~m}^{-2}$, which was more than twice the amount of peak power obtained with carbon cloth cathodes $\left(151 \mathrm{~mW} \mathrm{~m}^{-2}\right)$ [183]. 
The activity of single-walled CNTs with carboxyl groups, multi-walled CNTs with carboxyl groups and multi-walled CNTs with hydroxyl-groups as anodes have also been compared [184]. Multi-walled CNTs have been reported to provide better results than singlewalled CNTs; a power density of $167 \mathrm{~mW} \mathrm{~m}^{-2}$ was achieved by the multi-walled CNT with hydroxyl groups, which was $130 \%$ more effective than the carbon cloth control [184]. MWCNTs with hydroxyl functional groups are a possible alternative anode material to traditionally used carbon cloth, due to their greatly improved performance in electron transfer capabilities, microbial attachment and substrate diffusion/oxidation rates [184].

\subsection{Non-Carbon Based Electrodes}

Despite carbon-based electrodes being the electrode of choice in MFC configurations due to their versatility in structure, non-carbon based electrodes have also been utilised in MFCs. In 2007, Dumas et al, produced a MFC that consisted of a stainless steel anode and cathode. The anode was embedded into marine sediment, which was coupled to the cathode in the overlying seawater [84]. The maximum power density produced by this SMFC configuration resulted in a lower output $\left(4 \mathrm{~mW} \mathrm{~m}^{-2}\right)$ than the laboratory control $\left(23 \mathrm{~mW} \mathrm{~m}^{-2}\right)$ [84]. It was suggested that this might be due to biofilm damage on the cathode, due to grazing fish and possible damage to electrical connections by waves [84]. These results can be compared against carbon-based electrodes utilised within SMFCs (with similar-sized anodes: $\sim 0.18 \mathrm{~m}^{2}$ ) with a graphite plate anode with a stainless steel cathode $\left(12 \mathrm{~mW} \mathrm{~m}^{-2}\right)$, plain graphite electrodes $\left(28 \mathrm{~mW} \mathrm{~m}^{-2}\right)$ and a single graphite rod anode with a carbon brush cathode $(34 \mathrm{~mW}$ $\left.\mathrm{m}^{-2}\right)$ [84, 185-187].

Commercial platinum-coated titanium metal (deposited by electroplating) and uncoated titanium have also been trailed as non-porous bioanodes, and were compared against flat and roughened graphite [188]. Polarization curves and impedance spectroscopy showed that bioanode performance decreased in the order roughened graphite $>$ platinum coated titanium $>$ flat graphite $>$ uncoated titanium [188]. The uncoated titanium anode produced the lowest current, whilst the anode potential was considerably higher than the other electrodes $(>-150$ $\mathrm{mV} v s . \mathrm{Ag} / \mathrm{AgCl}$ at $R=1000 \Omega$ ) [188]. This result may have been due to anodic passivation of the titanium, suggesting that uncoated titanium is an unsuitable anode material for MFC set-ups [188].

A study by Baudler et al, in 2015 compared the performance of gold, silver, copper, nickel, cobalt and titanium electrodes against a graphitic benchmark (Figure 8) [189]. The 
average maximum current densities demonstrated that of the three most noble metals, copper produced the highest maximum current density $\left(1515 \mu \mathrm{A} \mathrm{cm}^{-2}\right)$, followed by gold $(1175 \mu \mathrm{A}$ $\mathrm{cm}^{-2}$ ) and silver $\left(1119 \mu \mathrm{A} \mathrm{cm}^{-2}\right)$, which were slightly higher than that of the graphite control $\left(984 \mu \mathrm{A} \mathrm{cm}^{-2}\right)$ [189]. The results for silver and copper are surprising, as these metals are well established in their application as antimicrobial metals, and have been studied extensively i.e. for implementation as surface coatings for medical devices/equipment [190-192]. However, it was demonstrated that electrochemically active, electrode respiring bacteria from secondary biofilms (which are highly Geobacter dominated) have the ability to adhere to, colonise and form highly active biofilms on both copper and silver electrodes. These produced biofilm thicknesses of $249 \pm 21 \mu \mathrm{m}$ and $154 \pm 10 \mu \mathrm{m}$, respectively [189]. In light of this, copper and silver electrodes could play a pivotal role in the optimisation of MFCs. Of the non-noble metals (titanium, cobalt, nickel and stainless steel) stainless steel produced the highest average maximum current density $\left(674 \mu \mathrm{A} \mathrm{cm}^{-2}\right)$ followed by nickel $\left(384 \mu \mathrm{A} \mathrm{cm}^{-2}\right)$.

However, the current densities produced by cobalt and titanium were negligible in comparison to the other electrode materials [189]. This marked decrease in current density by the non-noble metals may be attributed to the formation of metal oxides, acting as a barrier in charge transfer processes between the biofilms and the metals [189, 193].

The suitability of gold electrodes for use within MFCs has also demonstrated by Ritcher et al, which were used in conjunction with G. sulfurreducens (ATCC 51573), with $10 \mathrm{mM}$ acetate as the electron donor and $40 \mathrm{mM}$ fumarate as the electron acceptor [194]. The results showed that the current stabilised at $0.4 \mathrm{~mA}-0.7 \mathrm{~mA}$ after $c a .6-10$ days and that this maximum current was comparable to carbon fibre anodes under the same conditions [194, 195]. The ability to transfer electrons to the gold anode was postulated to be due to the direct contact between G. sulfurreducens via micro-nanowires (pili). However, work by others has suggested that using gold electrodes with Shewanella putrefaciens, was not suitable for use within MFCs [196]. A possible explanation for this variation in electrochemical response between the bacterial species' could be due to the differences in electron transfer mechanisms, as $G$. sulfurreducens is associated with direct electron transfer, whilst $S$. putrefaciens is associated with redox proteins displayed on the surface of bacterial cells, such as c-type cytochromes [60, 194, 197]. Thus, the interactions of the different electrochemical pathways of the bacteria with the surfaces may have resulted in the conflicting results.

\section{Mechanisms of Electron Transport}


Exoelectrogenic bacterial species have the ability to facilitate electron transfer via two mechanisms, direct and indirect electron transfer [198]. Direct electron transfer requires a physical connection between the bacterial cell and the electrode surface, namely nanowires and/or redox-active proteins. Indirect electron transfer does not require a physical connection but instead this mechanism relies on electron shuttling molecules [199]. There are currently 3 established methods of electron transfer (e.g. nanowires, membrane bound cytochromes and electron mediators) which bacteria can utilise to donate electrons to the anode in a MFC configuration (Figure 9) [200].

\subsection{Direct electron transfer via conductive pili}

Bacterial colonies isolated in the anodic chamber of a fuel cell are incapable of transferring electrons directly to the electrode [1]. However, anodophiles have the ability to use electrons (in the anode) as their end electron acceptor. Thus, these specific bacterial species are involved in electron transfer, leading to the generation of an electrical charge [201]. A major breakthrough in MFC technology was observed by Kim et al, who demonstrated that electron transfer does not always need mediator (electron transfer) compound molecules [157]. The bacterial cell surface of specific isolated bacterial species, such as Shewanella spp., and Geobacter spp., have micrometre long proteinaceous filaments that extend from their outer surface into the extracellular matrix. These appendages are thought to be involved in extracellular electron transport processes, referred to as microbial nanowires - due to their long filament-like appearance and conductive attributes [202].

Nanowires can be either flagella or pili, both of which have very distinct properties, and therefore we propose the terms micro-nanowires and macro-nanowires (Figure 10). Traditionally, the major role of the flagellum of bacteria is to mediate the motility of the cell via swarming and swimming, allowing for colony expansion on a surface. One of the roles of Type IV pili is to mediate twitching to pull the cell across a surface (often in dense aggregates) [203]. Nanowires have the ability to partake in direct electron mediated transfer. Type IV pili play vital roles in secretion systems for effectors, microbial adherence and bacterial movement, establishing contact between the bacterial species and the electrode surface [204]. Reguera et al, showed that wild type G. sulfurreducens could attach to Fe(III) oxides after 48 hours, as demonstrated by an increase in biomass. However, in the same time period, the pilA-deficient strain could not grow, which was indicated by a decrease in biomass [205]. In regards to the bacterial species evaluated for electricity generation for potential application in microbial fuel cell technologies, G. sulfurreducens is currently the 
"gold standard", producing the highest recorded current densities of any known pure culture, utilising micro-nanowires (Figure 10) [206-208].

G. sulfurreducens is a Gram - negative, $\delta$-proteobacterium, and is a rod shaped, nonfermentative, obligate anaerobe, with flagella and type IV pili production. G. sulfurreducens is able to generate energy in the form of adenosine triphosphate, due to its ability to reduce metals such as Fe(III), by using metal ion-mediated electron transport mechanisms to oxidise organic compounds to $\mathrm{CO}_{2}$ [209]. The electrically conductive pili of $G$. sulfurreducens play a pivotal role in long-range electron transfer. Pilus conductivity is dependent upon $\mathrm{pH}$ levels, with a reduction in conductivity observed in a higher $\mathrm{pH}(\mathrm{pH} 10)-37 \pm 15 \mu \mathrm{S} \mathrm{cm}^{-1}$. However, a marked increase was noted at $\mathrm{pH} 2$, where the electrical conductivity of $188 \pm 33$ $\mathrm{mS} \mathrm{cm} \mathrm{cm}^{-1}$ was also produced from individual pili [210].

It is thought that the reduction of iron (and other metal) oxides by G. sulfurreducens requires direct contact between the bacteria and the Fe(III) oxides. This is in order to reduce equivalents from the tricarboxylic acid cycle (TCA), also known as the Krebs cycle [211]. This ability to locate (via chemotaxis) and reduce Fe(III) oxides in order to use them as terminal electron acceptors is advantageous in subsurface environments due to the abundance of Fe(III) oxides [209, 212]. Both nicotinamide adenine dinucleotide phosphate (NADPH) and nicotinamide adenine dinucleotide (NADH) have the capability to transfer reducing equivalents to the electron transport chain, during fumarate reduction by G. sulfurreducens. This provides a source of ATP from the iron oxides [211].

The current density generated by a monolayer of planktonic cells attached to the surface of an electrode is limited by the surface area of the electrode. It is thought that this is presumably due to a lack of available space for the nanowires to adhere to, thus leading to a reduction in direct electron transfer [213]. Therefore, it is of little surprise that conductive biofilms (which are many layers thick) have the ability to produce much higher power and current densities, due to multiple layers of bacteria contributing to the overall net energy generation. Friman et al, described a current generation (under a constant external resistor of $1 \mathrm{k} \Omega$ ) of $125 \mathrm{~mA} \mathrm{~m}^{-2}$ from planktonic cells as opposed to $541 \mathrm{~mA} \mathrm{~m}^{-2}$ from an established biofilm, where acetate was used as the substrate with a pure culture of Cupriavidus basilensis [213]. Conductivity measurements with G. sulfurreducens in biofilm formulations have shown high conductivities, even rivalling those of synthetic conductive polymers [207]. $G$. sulfurreducens, in multi-layered biofilms of an average height of $40 \mu \mathrm{m}( \pm 6 \mu \mathrm{m})$, produced a maximum current of $12 \mathrm{~mA}$, while the planktonic cells produced a maximum current of 2.5 $\mathrm{mA}$, [205] after 4 days of incubation using a continuous batch method [214]. 


\subsection{Direct electron transfer via redox-active proteins}

Most studies suggest that the direct contact by pili of the conductive bacterial biofilms and the iron oxides is essential for the reduction of iron oxides. However, another mechanism of electron transfer requires redox active proteins and allows for short-range electron transfer to take place [215]. $C$-type cytochromes are commonly known for their primary function in mitochondria, as these molecules play a pivotal role in ATP synthesis [216]. Smith et al, revealed that deletion of the gene encoding for PilA, a structural pilin protein in the KN400 strain of G. sulfurreducens inhibited iron oxide reduction [217]. One possible explanation for the continued iron reduction even with structurally damaged pili is the utilisation of $c$-type cytochromes, such as OmcS and OmcE [218].

$C$-type cytochromes were found in abundance on the surface of $G$. sulfurreducens cells, with OmcS and OmcE being the most commonly isolated. It has been shown that when either $o m c S$ or $o m c E$ genes were deleted, reduction of iron (III) oxides could no longer take place [219]. Immunolocalization and proteolysis studies have also demonstrated that the cytochrome, OmcB is essential for optimal Fe (III) reductions, it is both highly expressed during growth upon electrode surfaces and is embedded in the outer membrane of the cell [220-222]. It has been suggested that bacteria such as G. sulfurreducens developed this ability to reduce metal oxides such as iron, due to being isolated in harsh environments surrounded by large quantities of insoluble materials. Therefore, natural selection and evolution have led to the production of effective strategies to overcome the lack of ATP production that is usually achieved by more conventional methods, i.e. aerobic respiration $[223,224]$. Thus, the genome of $G$. sulfurreducens gained the ability to reduce iron oxides due to selection pressure. Therefore, it may be speculated that such mutations may lead to improved degradation of iron oxides, in order to increase ATP production $[225,226]$.

\subsection{In-direct electron transfer via electron shuttles}

Bacteria can generate electricity due to the production of secondary metabolites, which are able to act as endogenous redox mediators, often referred to as electron shuttles. Electron shuttles are organic molecules with a low molecular weight that have the ability to catalyse both reduction and oxidation reactions, using for example phenazines and quinones [227]. Bacterial cells can utilise both added/in solution (exogenous) or self-produced/on bacterial cell surface (endogenous) shuttle compounds for extracellular electron transfer. 
However, for effective electron transfer to take place, electron shuttles must be both chemically-stable and not easily biologically degraded (Figure 11) [227].

Unlike conductive pili, electron shuttles eliminate the need of direct contact between the bacterial cell and the electron acceptor (which in the case of MFCs is the electrodes) [202]. Within the bacterial cells, electrons are first transported to the cell surface via a metabolic pathway, which involves redox-active proteins and low molecular weight compounds. Subsequently, electrons are then transported to cytochromes or potential shuttles in either the periplasm or the outer-membrane [227]. Soluble electron shuttles can diffuse into the medium surrounding the bacterial cell, and once outside, the electrons can be transferred to suitable external acceptors, with examples including insoluble Fe (III) oxides or a MFC anode [227]. Some compounds shown to be effective electron shuttles include thionine, methyl viologen, 2-hydroxy-1,4-naphtoquinone, methylene blue, humic acids and anthraquinone-2,6-disulfonic acid [228-231]. Other more common examples of electron shuttles are molecules known as flavins.

Flavins demonstrate enhanced efficiency when partaking in bio-geochemical iron cycles, and redox potentials, which improves electron transfer. Thus, flavins have the potential to be applied to MFC technologies as such molecules can be used as endogenous electron transfer mediators [232]. Further, the importance of flavins as electron shuttles, have been shown, as the concentration of flavins increased from $0.2 \mu \mathrm{m}-0.6 \mu \mathrm{m}$ to $4.5 \mu \mathrm{m}-5.5$ $\mu \mathrm{m}$ the peak current produced by $S$. oneidensis became four times greater [227].

Flavins are often produced as secondary metabolites in bacteria, for example, riboflavin which is also known as vitamin B2. This compound has been shown to act as an electron shuttle by Marsili et al, when $S$. oneidensis biofilms were analysed [233]. Results showed that the removal of riboflavin from biofilms resulted in a reduction of electron transfer rate to the electrodes by more than $70 \%$ [233]. Another example of a flavin is pyocyanin, this has been shown to mediate electron transfer in MFCs [234]. The concentration of pyocyanin in an anodic culture has shown a direct correlation to power generation efficiency, due to its ability to transport electrons through the cell membrane [235]. Pyocyanin is produced as a secondary metabolite by Pseudomonas aeruginosa, it is a water-soluble blue green phenazine compound, responsible for the green pigmentation often associated with infected wounds [236]. The production of pyocyanin by $P$. aeruginosa is of paramount importance due to its versatile nature. Pyocyanin has multiple functions including antimicrobial activity against a range of microorganisms (including bacteria, fungi and 
protozoa), an electron shuttle and a key sensing molecule to upregulate the transcription of quorum sensing genes, leading to biofilm formation [237-245].

\subsection{Mixed community microbial fuel cells}

The different mechanisms in which bacteria can facilitate electron transfer has been considered, however, few monoculture strains have the capacity to produce power densities as great as strains that are inoculated in mixed communities. For example, enriched anodic biofilms have previously been shown to generate power densities as high as $6.9 \mathrm{~W}$ per $\mathrm{m}^{2}$ (projected anodic area) [25]. Some bacteria found in MFC biofilms have shown that the cells do not interact directly with the anode, however through interactions with other bacteria they can still contribute indirectly to the production of electricity. One example of this has been demonstrated by Brevibacillus spp., (strain PTH1), which was found in abundance in a MFC community. Power production from this bacterial subclass alone is low, however when cocultured with Pseudomonas spp., (or supernatant from an MFC community containing Pseudomonas spp.,) there was a marked increase in electricity generation [246].

Specific members of fluorescent Pseudomonads can produce and secreet phenazines i.e. pyocyanin production by $P$. aeruginosa strains [243]. The effect of pyocyanin addition to non-pyocyanin producing MFC biofilms has shown varying results. Rabaey et al, demonstrated that the addition of pyocyanin to a pure culture of Enterococcus faecium (strain KRA3), led to a peak power increase from $294 \pm 49 \mu \mathrm{W} \mathrm{m}^{-2}$ to $3977 \pm 612 \mu \mathrm{W} \mathrm{m}{ }^{-2}$, a 13-fold increase [246]. However, against E. coli (ATCC 4157), the power output showed a reduction by $50 \%$, after the addition of pyocyanin $\left(117 \pm 16 \mu \mathrm{W} \mathrm{m}{ }^{-2}\right.$ to $50 \pm 53 \mu \mathrm{W} \mathrm{m}^{-2}$ [246]. A possible explanation for this could be due to the selective antimicrobial activity of redoxactive proteins such as pyocyanin $[237,238]$. Pyocyanin, has shown greater antimicrobial activity against aerobic bacterial strains; in 1981 Baron and Rowe showed that facultative anaerobes were two-fold (or more) resistant [237]. The addition of pyocyanin (or pyocyanin producing strains of bacteria e.g. P. aeruginosa) to non-pyocyanin producing biofilms could therefore be used to increase power outputs. One example, where this approach could be applied is the degradation of waste/toxic matter (such as toluene) to efficiently convert organic matter to electricity in a MFC set-up [247]. However, significance should be placed upon the selection of bacteria utilised within mixed community biofilms MFC configurations, ensuring resistance to the antimicrobial effects of exogenous redox mediators. 
The interactions of mixed community biofilms is complex and is yet to be fully understood. However, the use of mixed community biofilms, both inter-bacterial and other microorganisms (i.e. fungi such as yeast) for MFCs, has vast potential. A pure culture MFC (G. sulfurreducens) was shown to produce a maximum power of $461 \pm 8 \mathrm{~mW} \mathrm{~m}^{-2}$, compared to a mixed community biofilm MFC that produced a maximum power of $576 \pm 25 \mathrm{~mW} \mathrm{~m}^{-2}$ under the same conditions [248]. Another study, which used the fungus Trametes versicolor and $S$. oneidensis in combination, showed that the bacterial-fungal interactions enhanced power generation, producing a maximum power density of $0.78 \mathrm{~W} \mathrm{~m}^{-3}$ [249]. Fernández de Dios et al, suggested that the bacterium was capable of both adhering to and transporting electrons from the T. versicolor filamentous networks. Further, T. versicolor can produce oxidative enzymes, which provide an oxidoreductase mechanism, which involves the transportation of electrons from donor to acceptor [249]. Clearly mixed biofilm communities, that have the ability to generate electricity by more than one mechanism, will play a pivotal role in the improvement of MFCs [250].

\section{Field standardisation and comparison techniques}

Differences in MFC configurations, including architectures, anode/cathode/PEM materials and solution chemistries have hindered the progression of MFC technologies, due to the lack of direct comparisons of power production available [117]. In the late 1980's, Bennetto et al studied synthetic mediators, and this resulted in the development of the "analytical MFC" that is still used by a number of research groups to date [35, 251]. Furthermore, over the last decade researchers have also started to use another MFC design whilst carrying out experiments [88, 117, 252-256]. This design utilises a single-chamber cube shaped MFC (4 cm) with a $3 \mathrm{~cm}$ (diameter) analyte chamber, a graphite fibre brush anode and a platinum cathode catalyst [117]. This configuration usually uses $50 \mathrm{mM}$ phosphate buffer solution and acetate as a fuel source [117]. The use of identical MFC designs and conditions throughout the field allows for direct comparisons between energygeneration results from a wide array of laboratories [117]. In order to improve power outputs from MFC technologies, the design of the MFCs need to be detailed (e.g. distance between electrodes, PEM type etc.), allowing for appropriate comparisons and identification of factors capable of improving energy generation.

One issue that greatly hinders the advancement of MFC technologies is the lack of consistency and standardisation in regards to stringent comparisons of energy outputs of MFCs (Table 1) [257]. Current density is the most typically used performance indicator of 
MFCs at a set potential which is typically calculated in watts per square meter $\left(\mathrm{W} \mathrm{m}^{-2}\right)$, and measures power output in relation to the surface area of the anode [257, 258]. However, the use of surface based power density has many limitations, making it unsuitable for measuring MFC energy generation. One major limitation is that it is difficult to measure the exact surface area of porous electrodes, and therefore it is often estimated as the projected surface area [257]. Further, surface areas of porous electrodes of identical size could vary drastically between similar electrodes [257]. Another way to quantify energy outputs from MFCs is watts per cubic meter $\left(\mathrm{W} \mathrm{m}^{-3}\right)$, which takes into account the anode liquid volume but excludes variation in the electrode size and configuration [257]. Traditional performance indicators such as current/power density, resistance, impedance and capacitance testing can all provide vital information [259]. Ge et al, proposed a new parameter in order to effectively describe energy generation from MFCs, and this term is the normalised energy recovery (NER), which gives energy generation in $\mathrm{kWh} \mathrm{m}^{-3}[257,260]$ :

$$
N E R=\frac{\text { power } \times \text { time }(t)}{\text { wastewater volume }(\text { treated within time }(t))}=\frac{\text { Power }}{\text { wastewater flow rate }}
$$

However, this calculation assumes that all MFC technologies are wastewater treatment systems but this is not the case [260]. Equation (3) can be modified in order to take into account the organic substrates present in solution, based on the removed chemical oxygen demand (COD) in kilowatt hours per kilogram of COD [kWh (kg COD) $\left.{ }^{-1}\right]$ [257]:

$$
N E R=\frac{\text { power } \times \text { time }(t)}{\operatorname{COD}(\text { removed within time }(t))}=\frac{\text { power }}{\text { wastewater flow rate } \times \triangle C O D}
$$

Such performance power indicators will allow for a better understanding of organic compound conversion to energy via MFCs.

\section{Conclusions}

MFC technologies have the potential to play a pivotal role in the transition from fossil fuel based technologies to more renewable energy sources. Research into this area is clearly progressing but there is still much more to do in order for MFC technologies to be routinely adapted into industry and society. This review provides an overview of MFC technologies thus far, whilst benchmarking MFC performance and limitations. Currently the highest power output from an MFC is comparable to that of a PEM hydrogen fuel cell; however, further 
progression of this field is expected. This expected advancement will be due to the optimisation and tailored development of individual parameters such as, enhanced electrode materials that are more suitable for this application. This, alongside interdisciplinary research intoexoelectrogenic bacteria, their biochemical pathways and the influence of secondary metabolites that underpin electron transfer mechanisms, could lead to power outputs much closer to that of the theoretical limits, as well as furthering the advancing field of electromicrobiology. 


\section{Acknowledgements}

This work was supported by the Engineering and Physical Sciences Research Council (Reference: EP/N001877/1); and British Council Institutional Grant Link (No. 172726574). The Manchester Fuel Cell Innovation Centre is funded by the European Regional Development Fund. D. A. C. Brownson acknowledges funding from the Ramsay Memorial Fellowships Trust. Copyright permission was obtained for the images used throughout this review prior to publication. The authors declare no competing financial interests. The authors would like to thank Dr. Jonathan Butler for his assistance with the preparation and proof reading of this manuscript.

\section{Conflicts of interest}

The authors declare they have no competing interests. 


\section{References}

[1] Du Z, Li H, Gu T. A state of the art review on microbial fuel cells: A promising technology for wastewater treatment and bioenergy. Biotechnol Adv 2007;25:464-82.

[2] Davis F, Higson SPJ. Biofuel cells-Recent advances and applications. Biosens Bioelectron 2007;22:1224-35.

[3] Granqvist CG. Transparent conductors as solar energy materials: A panoramic review. Sol Energy Mater Sol Cells 2007;91:1529-98.

[4] Herbert GJ, Iniyan S, Sreevalsan E, Rajapandian S. A review of wind energy technologies. Renew Sust Energ Rev 2007;11:1117-45.

[5] Antonio FdO. Wave energy utilization: A review of the technologies. Renew Sust Energ Rev 2010;14:899-918.

[6] Lund JW, Freeston DH, Boyd TL. Direct utilization of geothermal energy 2010 worldwide review. Geothermics 2011;40:159-80.

[7] Berndes G, Hoogwijk M, van den Broek R. The contribution of biomass in the future global energy supply: a review of 17 studies. Biomass Bioenergy 2003;25:1-28.

[8] Panwar N, Kaushik S, Kothari S. Role of renewable energy sources in environmental protection: a review. Renew Sust Energ Rev 2011;15:1513-24.

[9] Khare V, Nema S, Baredar P. Solar-wind hybrid renewable energy system: A review. Renew Sust Energ Rev 2016;58:23-33.

[10] Yilanci A, Dincer I, Ozturk HK. A review on solar-hydrogen/fuel cell hybrid energy systems for stationary applications. Prog Energy Combust Sci 2009;35:231-44.

[11] Habermann W, Pommer E. Biological fuel cells with sulphide storage capacity. Appl Microbiol Biotechnol 1991;35:128-33.

[12] Potter MC. Electrical Effects Accompanying the Decomposition of Organic Compounds. Proc R Soc Lond [Biol] 1911;84:260-76.

[13] Cohen B. The bacterial culture as an electrical half-cell. J Bacteriol 1931;21:18-9.

[14] Schröder U. Discover the possibilities: microbial bioelectrochemical systems and the revival of a 100-year-old discovery. J Solid State Electrochem 2011;15:1481-6.

[15] Guo K, Hassett DJ, Gu T. Microbial Fuel Cells: Electricity Generation from Organic Wastes by Microbes. In: Microbial Biotechnology: Energy and Environment, editors. Arora, R, United

Kingdom: CAB International; 2012, p.162-89.

[16] Canfield J, Goldner B, Lutwack R. NASA Technical report. Magna Corporation, Anaheim, CA. $1963 ; 63$.

[17] Rabaey K, Verstraete W. Microbial fuel cells: novel biotechnology for energy generation. Trends Biotechnol 2005;23:291-8.

[18] Kim BH, Park DH, Shin PK, Chang IS, Kim HJ. Mediator-less biofuel cell. Google Patents; 1999.

[19] Kim HJ, Hyun MS, Chang IS, Kim BH. A microbial fuel cell type lactate biosensor using a metal-reducing bacterium, Shewanella putrefaciens. J Microbiol Biotechnol 1999;9:365-7.

[20] Nader M, Wan R, Rahimnejad M, Najafpour G. Bioelectricity generation in biological fuel cell with and without mediators. World Appl Sci J 2012;18:559-67.

[21] Pant D, Van Bogaert G, Diels L, Vanbroekhoven K. A review of the substrates used in microbial fuel cells (MFCs) for sustainable energy production. Bioresour Technol 2010;101:1533-43.

[22] Rahimnejad M, Jafary T, Haghparast F, Najafpour G, Ghoreyshi AA. Nafion as a nanoproton conductor in microbial fuel cells. Turkish J Eng Env Sci 2011;34:289-92.

[23] Rahimnejad M, Adhami A, Darvari S, Zirepour A, Oh S-E. Microbial fuel cell as new technology for bioelectricity generation: A review. Alexandria Eng J 2015;54:745-56.

[24] Logan BE, Hamelers B, Rozendal R, Schroder U, Keller J, Freguia S, et al. Microbial fuel cells: methodology and technology. Environ Sci Technol 2006;40:5181-92.

[25] Logan BE, Regan JM. Electricity-producing bacterial communities in microbial fuel cells. Trends Microbiol 2006;14:512-8. 
[26] Moon H, Chang IS, Kang KH, Jang JK, Kim BH. Improving the dynamic response of a mediator-less microbial fuel cell as a biochemical oxygen demand (BOD) sensor. Biotechnol Lett 2004;26:1717-21.

[27] Manish S, Banerjee R. Comparison of biohydrogen production processes. Int J Hydrogen Energy 2008;33:279-86.

[28] Min B, Cheng S, Logan BE. Electricity generation using membrane and salt bridge microbial fuel cells. Water Res 2005;39:1675-86.

[29] Logan BE. Peer reviewed: extracting hydrogen and electricity from renewable resources. Environ Sci Technol 2004;38:160-67.

[30] Parkash A. Microbial fuel cells: a source of bioenergy. J Microb Biochem Technol 2016;8:24755.

[31] Kumar R, Singh L, Zularisam AW. Exoelectrogens: Recent advances in molecular drivers involved in extracellular electron transfer and strategies used to improve it for microbial fuel cell applications. Renew Sust Energ Rev 2016;56:1322-36.

[32] Regan JM, Yan H. Microbial Community Characterization on Polarized Electrode Surfaces In:Biofilms in Bioelectrochemical Systems: From Laboratory Practice to Data Interpretation editors. Beyenal H, Babauta J, Wiley \& Sons, Incorporated; 2015: p. 61-82.

[33] Rismani-Yazdi H, Carver SM, Christy AD, Tuovinen OH. Cathodic limitations in microbial fuel cells: an overview. J Power Sources 2008;180:683-94.

[34] Zhao F, Harnisch F, Schröder U, Scholz F, Bogdanoff P, Herrmann I. Challenges and constraints of using oxygen cathodes in microbial fuel cells. Environ Sci Technol 2006;40:5193-9.

[35] Santoro C, Arbizzani C, Erable B, Ieropoulos I. Microbial fuel cells: From fundamentals to applications. A review. J Power Sources 2017;356:225-44.

[36] Wang H, Luo H, Fallgren PH, Jin S, Ren ZJ. Bioelectrochemical system platform for sustainable environmental remediation and energy generation. Biotechnol Adv 2015;33:317-34.

[37] Li Y, Wu Y, Liu B, Luan H, Vadas T, Guo W, et al. Self-sustained reduction of multiple metals in a microbial fuel cell-microbial electrolysis cell hybrid system. Bioresour Technol 2015;192:23846.

[38] Nancharaiah Y, Mohan SV, Lens P. Metals removal and recovery in bioelectrochemical systems: a review. Bioresour Technol 2015;195:102-14.

[39] Heijne AT, Liu F, Weijden Rvd, Weijma J, Buisman CJ, Hamelers HV. Copper recovery combined with electricity production in a microbial fuel cell. Environ Sci Technol 2010;44:4376-81. [40] Ntagia E, Rodenas P, Ter Heijne A, Buisman C, Sleutels T. Hydrogen as electron donor for copper removal in bioelectrochemical systems. Int J Hydrogen Energy 2016;41:5758-64.

[41] Oh S-E, Logan BE. Proton exchange membrane and electrode surface areas as factors that affect power generation in microbial fuel cells. Appl Microbiol Biotechnol 2006;70:162-9.

[42] Erable B, Feron D, Bergel A. Microbial catalysis of the oxygen reduction reaction for microbial fuel cells: a review. ChemSusChem 2012;5:975-87.

[43] Niessen J, Schröder U, Rosenbaum M, Scholz F. Fluorinated polyanilines as superior materials for electrocatalytic anodes in bacterial fuel cells. Electrochem Commun 2004;6:571-5.

[44] Zhang E, Xu W, Diao G, Shuang C. Electricity generation from acetate and glucose by sedimentary bacterium attached to electrode in microbial-anode fuel cells. J Power Sources 2006;161:820-5.

[45] Liu H, Ramnarayanan R, Logan BE. Production of electricity during wastewater treatment using a single chamber microbial fuel cell. Environ Sci Technol 2004;38:2281-5.

[46] Liu H, Cheng S, Logan BE. Production of Electricity from Acetate or Butyrate Using a SingleChamber Microbial Fuel Cell. Environ Sci Technol 2005;39:658-62.

[47] Kim BH, Chang IS, Gadd GM. Challenges in microbial fuel cell development and operation. Appl Microbiol Biotechnol 2007;76:485-94.

[48] Kim JR, Cheng S, Oh SE, Logan BE. Power generation using different cation, anion, and ultrafiltration membranes in microbial fuel cells. Environ Sci Technol 2007;41:1004-9.

[49] Rowley-Neale SJ, Fearn JM, Brownson DA, Smith GC, Ji X, Banks CE. 2D molybdenum disulphide (2D-MoS 2) modified electrodes explored towards the oxygen reduction reaction.

Nanoscale 2016;8:14767-77. 
[50] Logan BE. Exoelectrogenic bacteria that power microbial fuel cells. Nat Rev Micro 2009;7:37581.

[51] Capodaglio AG, Molognoni D, Dallago E, Liberale A, Cella R, Longoni P, et al. Microbial Fuel Cells for Direct Electrical Energy Recovery from Urban Wastewaters. Sci World J 2013;2013:No Pagination.

[52] Rozendal RA, Hamelers HV, Rabaey K, Keller J, Buisman CJ. Towards practical implementation of bioelectrochemical wastewater treatment. Trends Biotechnol 2008;26:450-9.

[53] Mustakeem M. Electrode materials for microbial fuel cells: nanomaterial approach. Mater Renew Sustain Energy 2015;4:22-32.

[54] Dong Y, Feng Y, Qu Y, Du Y, Zhou X, Liu J. A combined system of microbial fuel cell and intermittently aerated biological filter for energy self-sufficient wastewater treatment. Sci Rep 2015;5:18070.

[55] Wang Y-Z, Wang Y-K, He C-S, Yang H-Y, Sheng G-P, Shen J-Y, et al. Hydrodynamics of an electrochemical membrane bioreactor. Sci Rep 2015;5:10387.

[56] Zhang B, Zhao H, Zhou S, Shi C, Wang C, Ni J. A novel UASB-MFC-BAF integrated system for high strength molasses wastewater treatment and bioelectricity generation. Bioresour Technol 2009; 100:5687-93.

[57] Ye T-r, Song N, Chen M, Yan Z-s, Jiang H-L. No enhancement of cyanobacterial bloom biomass decomposition by sediment microbial fuel cell (SMFC) at different temperatures. Environ Pollut 2016;218:59-65.

[58] Oh S, Logan BE. Hydrogen and electricity production from a food processing wastewater using fermentation and microbial fuel cell technologies. Water Res 2005;39:4673-82.

[59] Weber KA, Achenbach LA, Coates JD. Microorganisms pumping iron: anaerobic microbial iron oxidation and reduction. Nat Rev Micro 2006;4:752-64.

[60] Bond DR. Electricity production by Geobacter sulfurreducens attached to electrodes. Appl Environ Microbiol 2003;69:1548-55.

[61] Chae K-J, Choi M-J, Lee J-W, Kim K-Y, Kim IS. Effect of different substrates on the performance, bacterial diversity, and bacterial viability in microbial fuel cells. Bioresour Technol 2009;100:3518-25.

[62] Pant D, Van Bogaert G, De Smet M, Diels L, Vanbroekhoven K. Use of novel permeable membrane and air cathodes in acetate microbial fuel cells. Electrochim Acta 2010;55:7710-6.

[63] Parkash A, Aziz S, Soomro SA. Utilization of sewage sludge for production of electricity using mediated salt bridge based dual chamber microbial fuel cell. J Bioprocess Biotech 2015;5:No Pagination.

[64] Ortiz-Martínez VM, Gajda I, Salar-García MJ, Greenman J, Hernández-Fernández FJ, Ieropoulos I. Study of the effects of ionic liquid-modified cathodes and ceramic separators on MFC performance. Chem Eng J 2016;291:317-24.

[65] Wu X, Shi Z, Zou L, Li CM, Qiao Y. Pectin assisted one-pot synthesis of three dimensional porous $\mathrm{NiO} /$ graphene composite for enhanced bioelectrocatalysis in microbial fuel cells. J Power Sources 2018;378:119-24.

[66] Myung J, Yang W, Saikaly P, Logan BE. Copper current collectors reduce long-term fouling of air cathodes in microbial fuel cells. Environ Sci: Water Res Technol 2018;4:513-19.

[67] Ghasemi M, Shahgaldi S, Ismail M, Kim BH, Yaakob Z, Daud WRW. Activated carbon nanofibers as an alternative cathode catalyst to platinum in a two-chamber microbial fuel cell. Int $\mathrm{J}$ Hydrogen Energy 2011;36:13746-52.

[68] Winfield J, Greenman J, Huson D, Ieropoulos I. Comparing terracotta and earthenware for multiple functionalities in microbial fuel cells. Bioprocess Biosyst Eng 2013;36:1913-21.

[69] Jana PS, Behera M, Ghangrekar M. Performance comparison of up-flow microbial fuel cells fabricated using proton exchange membrane and earthen cylinder. Int J Hydrogen Energy 2010;35:5681-6.

[70] Mohanakrishna G, Abu-Reesh IM, Al-Raoush RI, He Z. Cylindrical graphite based microbial fuel cell for the treatment of industrial wastewaters and bioenergy generation. Bioresour Technol 2018;247:753-8.

[71] Qian F, Morse DE. Miniaturizing microbial fuel cells. Trends Microbiol 2011;29:62-9. 
[72] Ren H, Pyo S, Lee J-I, Park T-J, Gittleson FS, Leung FC, et al. A high power density miniaturized microbial fuel cell having carbon nanotube anodes. J Power Sources 2015;273:823-30.

[73] Choi S, Chae J. An array of microliter-sized microbial fuel cells generating $100 \mu \mathrm{W}$ of power. Sens Actuators A Phys 2012;177:10-5.

[74] He Z, Minteer SD, Angenent LT. Electricity generation from artificial wastewater using an upflow microbial fuel cell. Environ Sci Technol 2005;39:5262-7.

[75] Jayashree C, Tamilarasan K, Rajkumar M, Arulazhagan P, Yogalakshmi K, Srikanth M, et al. Treatment of seafood processing wastewater using upflow microbial fuel cell for power generation and identification of bacterial community in anodic biofilm. J Environ Manage 2016;180:351-8.

[76] Min B, Logan BE. Continuous Electricity Generation from Domestic Wastewater and Organic Substrates in a Flat Plate Microbial Fuel Cell. Environ Sci Technol 2004;38:5809-14.

[77] Kazemi S, Fatih K, Mohseni M. Improved performance of a passive air breathing flat-plate microbial fuel cell. Can J Chem Eng 2015;93:479-85.

[78] Mink JE, Qaisi RM, Logan BE, Hussain MM. Energy harvesting from organic liquids in microsized microbial fuel cells. NPG Asia Mater 2014;6:e89.

[79] Biffinger JC, Pietron J, Ray R, Little B, Ringeisen BR. A biofilm enhanced miniature microbial fuel cell using Shewanella oneidensis DSP10 and oxygen reduction cathodes. Biosens Bioelectron 2007;22:1672-9.

[80] Ringeisen BR, Henderson E, Wu PK, Pietron J, Ray R, Little B, et al. High power density from a miniature microbial fuel cell using Shewanella oneidensis DSP10. Environ Sci Technol 2006;40:2629-34.

[81] Logan BE, Wallack MJ, Kim K-Y, He W, Feng Y, Saikaly PE. Assessment of microbial fuel cell configurations and power densities. Environ Sci Technol Lett 2015;2:206-14.

[82] Rabaey K, Clauwaert P, Aelterman P, Verstraete W. Tubular microbial fuel cells for efficient electricity generation. Environ Sci Technol 2005;39:8077-82.

[83] Xu B, Ge Z, He Z. Sediment microbial fuel cells for wastewater treatment: challenges and opportunities. Environ Sci: Water Res Technol 2015;1:279-84.

[84] Dumas C, Mollica A, Féron D, Basséguy R, Etcheverry L, Bergel A. Marine microbial fuel cell: use of stainless steel electrodes as anode and cathode materials. Electrochim Acta 2007;53:468-73.

[85] Zabihallahpoor A, Rahimnejad M, Talebnia F. Sediment microbial fuel cells as a new source of renewable and sustainable energy: present status and future prospects. RSC Adv 2015;5:94171-83.

[86] Ewing T, Ha PT, Babauta JT, Tang NT, Heo D, Beyenal H. Scale-up of sediment microbial fuel cells. J Power Sources 2014;272:311-9.

[87] Tanisho S, Kamiya N, Wakao N. Microbial fuel cell using Enterobacter aerogenes. J electroanal chem interfacial electrochem 1989;275:25-32.

[88] Liu H, Logan BE. Electricity Generation Using an Air-Cathode Single Chamber Microbial Fuel Cell in the Presence and Absence of a Proton Exchange Membrane. Environ Sci Technol

2004;38:4040-6.

[89] Park DH, Zeikus JG. Improved fuel cell and electrode designs for producing electricity from microbial degradation. Biotechnol Bioeng 2003;81:348-55.

[90] Melhuish C, Ieropoulos I, Greenman J, Horsfield I. Energetically autonomous robots: Food for thought. Auton Robots 2006;21:187-98.

[91] Papaharalabos G, Greenman J, Melhuish C, Santoro C, Cristiani P, Li B, et al. Increased power output from micro porous layer (MPL) cathode microbial fuel cells (MFC). Int J Hydrogen Energy 2013;38:11552-8.

[92] Ieropoulos IA, Ledezma P, Stinchcombe A, Papaharalabos G, Melhuish C, Greenman J. Waste to real energy: the first MFC powered mobile phone. Phys Chem Chem Phys 2013;15:15312-6.

[93] Ledezma P, Stinchcombe A, Greenman J, Ieropoulos I. The first self-sustainable microbial fuel cell stack. Phys Chem Chem Phys 2013;15:2278-81.

[94] Aelterman P, Rabaey K, Pham HT, Boon N, Verstraete W. Continuous Electricity Generation at High Voltages and Currents Using Stacked Microbial Fuel Cells. Environ Sci Technol 2006;40:338894.

[95] Oh SE, Logan BE. Voltage reversal during microbial fuel cell stack operation. J Power Sources 2007;167:11-7. 
[96] Dekker A, Heijne AT, Saakes M, Hamelers HV, Buisman CJ. Analysis and improvement of a scaled-up and stacked microbial fuel cell. Environ Sci Technol 2009;43:9038-42.

[97] Logan BE. Scaling up microbial fuel cells and other bioelectrochemical systems. Appl Microbiol Biotechnol 2010;85:1665-71.

[98] Winfield J, Gajda I, Greenman J, Ieropoulos I. A review into the use of ceramics in microbial fuel cells. Bioresour Technol 2016;215:296-303.

[99] Yousefi V, Mohebbi-Kalhori D, Samimi A. Ceramic-based microbial fuel cells (MFCs): A review. Int J Hydrogen Energy 2017;42:1672-90.

[100] Ieropoulos IA, Stinchcombe A, Gajda I, Forbes S, Merino-Jimenez I, Pasternak G, et al. Pee power urinal-microbial fuel cell technology field trials in the context of sanitation. Environ Sci: Water Res Technol 2016;2:336-43.

[101] Pasternak G, Greenman J, Ieropoulos I. Comprehensive Study on Ceramic Membranes for LowCost Microbial Fuel Cells. ChemSusChem 2016;9:88-96.

[102] Gajda I, Greenman J, Melhuish C, Ieropoulos I. Simultaneous electricity generation and microbially-assisted electrosynthesis in ceramic MFCs. Bioelectrochemistry 2015;104:58-64.

[103] Thorne R, Hu H, Schneider K, Bombelli P, Fisher A, Peter LM, et al. Porous ceramic anode materials for photo-microbial fuel cells. J Mater Chem 2011;21:18055-60.

[104] Deng L, Li F, Zhou S, Huang D, Ni J. A study of electron-shuttle mechanism in Klebsiella pneumoniae based-microbial fuel cells. Chin Sci Bull 2010;55:99-104.

[105] Sharma Y, Li B. The variation of power generation with organic substrates in single-chamber microbial fuel cells (SCMFCs). Bioresour Technol 2010;101:1844-50.

[106] Sun M, Zhai L-F, Li W-W, Yu H-Q. Harvest and utilization of chemical energy in wastes by microbial fuel cells. Chem Soc Rev 2016;45:2847-70.

[107] Blanchet E, Erable B, De Solan M-L, Bergel A. Two-dimensional carbon cloth and threedimensional carbon felt perform similarly to form bioanode fed with food waste. Electrochem Commun 2016;66:38-41.

[108] Islam MA, Woon CW, Ethiraj B, Cheng CK, Yousuf A, Khan MMR. Ultrasound driven biofilm removal for stable power generation in microbial fuel cell. Energ Fuel 2016;31:968-76.

[109] Sun D, Cheng S, Wang A, Li F, Logan BE, Cen K. Temporal-spatial changes in viabilities and electrochemical properties of anode biofilms. Environ Sci Technol 2015;49:5227-35.

[110] Harnisch F, Wirth S, Schröder U. Effects of substrate and metabolite crossover on the cathodic oxygen reduction reaction in microbial fuel cells: platinum vs. iron (II) phthalocyanine based electrodes. Electrochem Commun 2009;11:2253-6.

[111] Winfield J, Ieropoulos I, Rossiter J, Greenman J, Patton D. Biodegradation and proton exchange using natural rubber in microbial fuel cells. Biodegradation 2013;24:733-9.

[112] Janicek A, Fan Y, Liu H. Design of microbial fuel cells for practical application: a review and analysis of scale-up studies. Biofuels 2014;5:79-92.

[113] Rinaldi A, Mecheri B, Garavaglia V, Licoccia S, Di Nardo P, Traversa E. Engineering materials and biology to boost performance of microbial fuel cells: a critical review. Energ Environ Sci 2008;1:417-29.

[114] Deng Q, Li X, Zuo J, Ling A, Logan BE. Power generation using an activated carbon fiber felt cathode in an upflow microbial fuel cell. J Power Sources 2010;195:1130-5.

[115] Ahn Y, Hatzell MC, Zhang F, Logan BE. Different electrode configurations to optimize performance of multi-electrode microbial fuel cells for generating power or treating domestic wastewater. J Power Sources 2014;249:440-5.

[116] Lefebvre O, Tan Z, Kharkwal S, Ng HY. Effect of increasing anodic $\mathrm{NaCl}$ concentration on microbial fuel cell performance. Bioresour Technol 2012;112:336-40.

[117] Yang W, Kim K-Y, Saikaly PE, Logan BE. The impact of new cathode materials relative to baseline performance of microbial fuel cells all with the same architecture and solution chemistry. Energ Environ Sci 2017;10:1025-1033.

[118] Kim N, Choi Y, Jung S, Kim S. Effect of initial carbon sources on the performance of microbial fuel cells containing Proteus vulgaris. Biotechnol Bioeng 2000;70:109-14.

[119] Yin Y, Huang G, Tong Y, Liu Y, Zhang L. Electricity production and electrochemical impedance modeling of microbial fuel cells under static magnetic field. J Power Sources 2013;237:58-63. 
[120] Zhao YN, Li XF, Ren YP, Wang XH. Effect of static magnetic field on the performances of and anode biofilms in microbial fuel cells. RSC Adv 2016;6:82301-8.

[121] Moore RL. Biological effects of magnetic fields: studies with microorganisms. Can J Microbiol 1979;25:1145-51.

[122] Foletti A, Grimaldi S, Lisi A, Ledda M, Liboff AR. Bioelectromagnetic medicine: the role of resonance signaling. Electromagn Biol Med 2013;32:484-99.

[123] Oliver SP, Boor KJ, Murphy SC, Murinda SE. Food safety hazards associated with consumption of raw milk. Foodborne Pathog Dis 2009;6:793-806.

[124] Miyakoshi J. Effects of static magnetic fields at the cellular level. Prog Biophys Mol Biol 2005;87:213-23.

[125] Li W-W, Sheng G-P, Liu X-W, Cai P-J, Sun M, Xiao X, et al. Impact of a static magnetic field on the electricity production of Shewanella-inoculated microbial fuel cells. Biosens Bioelectron 2011;26:3987-92.

[126] Katz E, Lioubashevski O, Willner I. Magnetic Field Effects on Cytochrome c-Mediated Bioelectrocatalytic Transformations. J Am Chem Soc 2004;126:11088-92.

[127] Niu C, Geng J, Ren H, Ding L, Xu K, Liang W. The strengthening effect of a static magnetic field on activated sludge activity at low temperature. Bioresour Technol 2013;150:156-62.

[128] Santos LO, Alegre RM, Garcia-Diego C, Cuellar J. Effects of magnetic fields on biomass and glutathione production by the yeast Saccharomyces cerevisiae. Process Biochem 2010;45:1362-7.

[129] Choi C, Kim M, Hong SW, Choi YS, Song YI, Kim S, et al. Performance of a Microbial Fuel Cell using a Magnet Attached Cathode. Bull Korean Chem Soc 2010;31:1729-31.

[130] Okada T, Wakayama NI, Wang L, Shingu H, Okano J-i, Ozawa T. The effect of magnetic field on the oxygen reduction reaction and its application in polymer electrolyte fuel cells. Electrochim Acta 2003;48:531-9.

[131] He Z, Angenent LT. Application of bacterial biocathodes in microbial fuel cells. Electroanalysis 2006;18:2009-15.

[132] Liu Z, Zhou L, Chen Q, Zhou W, Liu Y. Advances in Graphene/Graphene Composite Based Microbial Fuel/Electrolysis Cells. Electroanal 2016;29:652-61.

[133] Yang C-J. An impending platinum crisis and its implications for the future of the automobile. Energy Policy 2009;37:1805-8.

[134] Ghasemi M, Daud WRW, Hassan SHA, Oh S-E, Ismail M, Rahimnejad M, et al. Nanostructured carbon as electrode material in microbial fuel cells: A comprehensive review. J Alloys Compd 2013;580:245-55.

[135] Rosenberg B, Van Camp L, Krigas T. Inhibition of cell division in Escherichia coli by electrolysis products from a platinum electrode. Nature 1965;205:698-9.

[136] Wei J, Liang P, Huang X. Recent progress in electrodes for microbial fuel cells. Bioresour Technol 2011;102:9335-44.

[137] Chen P, Fryling MA, McCreery RL. Electron transfer kinetics at modified carbon electrode surfaces: the role of specific surface sites. Anal Chem 1995;67:3115-22.

[138] Park HI, Mushtaq U, Perello D, Lee I, Cho SK, Star A, et al. Effective and Low-Cost Platinum Electrodes for Microbial Fuel Cells Deposited by Electron Beam Evaporation. Energ Fuel 2007;21:2984-90.

[139] Walter XA, Forbes S, Greenman J, Ieropoulos IA. From single MFC to cascade configuration: The relationship between size, hydraulic retention time and power density. Sustainable Energy Technologies and Assessments 2016;14:74-9.

[140] Ye Z, Hou J, Ellis MW, Behkam B. ASME International Mechanical Engineering Congress and Exposition. ASME 2012 International Mechanical Engineering Congress and Exposition: American Society of Mechanical Engineers: 2012, p. 1409-14.

[141] Logan BE, Call D, Cheng S, Hamelers HV, Sleutels TH, Jeremiasse AW, et al. Microbial electrolysis cells for high yield hydrogen gas production from organic matter. Environ Sci Technol 2008;42:8630-40.

[142] Khan AF, Randviir EP, Brownson DA, Ji X, Smith GC, Banks CE. 2D Hexagonal Boron Nitride (2D-hBN) Explored as a Potential Electrocatalyst for the Oxygen Reduction Reaction. Electroanal 2016; 29:622-34. 
[143] Liu Y, Yue X, Li K, Qiao J, Wilkinson DP, Zhang J. PEM fuel cell electrocatalysts based on transition metal macrocyclic compounds.Coord Chem Rev 2016;315:153-77.

[144] Gao M-R, Xu Y-F, Jiang J, Zheng Y-R, Yu S-H. Water Oxidation Electrocatalyzed by an Efficient Mn3O4/CoSe2 Nanocomposite. J Am Chem Soc 2012;134:2930-3.

[145] Feng L, Chen Y, Chen L. Easy-to-Operate and Low-Temperature Synthesis of Gram-Scale Nitrogen-Doped Graphene and Its Application as Cathode Catalyst in Microbial Fuel Cells. ACS Nano 2011;5:9611-8.

[146] Qu L, Liu Y, Baek J-B, Dai L. Nitrogen-Doped Graphene as Efficient Metal-Free Electrocatalyst for Oxygen Reduction in Fuel Cells. ACS Nano 2010;4:1321-6.

[147] Li S, Hu Y, Xu Q, Sun J, Hou B, Zhang Y. Iron- and nitrogen-functionalized graphene as a nonprecious metal catalyst for enhanced oxygen reduction in an air-cathode microbial fuel cell. J Power Sources 2012;213:265-9.

[148] Deeke A, Sleutels TH, Hamelers HV, Buisman CJ. Capacitive bioanodes enable renewable energy storage in microbial fuel cells. Environ Sci Technol 2012;46:3554-60.

[149] Peng X, Yu H, Wang X, Zhou Q, Zhang S, Geng L, et al. Enhanced performance and capacitance behavior of anode by rolling $\mathrm{Fe} 3 \mathrm{O} 4$ into activated carbon in microbial fuel cells.

Bioresour Technol 2012;121:450-3.

[150] Yu M, Cheng X, Zeng Y, Wang Z, Tong Y, Lu X, et al. Dual-Doped Molybdenum Trioxide Nanowires: A Bifunctional Anode for Fiber-Shaped Asymmetric Supercapacitors and Microbial Fuel Cells. Angew Chem Int Ed 2016;55:6762-6.

[151] Wu Z-S, Sun Y, Tan Y-Z, Yang S, Feng X, Müllen K. Three-dimensional graphene-based macro-and mesoporous frameworks for high-performance electrochemical capacitive energy storage. J Am Chem Soc 2012;134:19532-5.

[152] Deeke A, Sleutels THJA, Heijne AT, Hamelers HVM, Buisman CJN. Influence of the thickness of the capacitive layer on the performance of bioanodes in Microbial Fuel Cells. J Power Sources 2013;243:611-6.

[153] Scarselli M, Castrucci P, De Crescenzi M. Electronic and optoelectronic nano-devices based on carbon nanotubes. J Phys Condens Matter 2012;24:No Pagination.

[154] Yang C, Denno ME, Pyakurel P, Venton BJ. Recent trends in carbon nanomaterial-based electrochemical sensors for biomolecules: A review. Anal Chim Acta 2015;887:17-37.

[155] Yu F, Wang C, Ma J. Applications of Graphene-Modified Electrodes in Microbial Fuel Cells. Materials 2016;9:807-33.

[156] Zhou M, Chi M, Luo J, He H, Jin T. An overview of electrode materials in microbial fuel cells. J Power Sources 2011;196:4427-35.

[157] Kim HJ, Park HS, Hyun MS, Chang IS, Kim M, Kim BH. A mediator-less microbial fuel cell using a metal reducing bacterium, Shewanella putrefaciens. Enzyme Microb Technol 2002;30:145-52. [158] Hays S, Zhang F, Logan BE. Performance of two different types of anodes in membrane electrode assembly microbial fuel cells for power generation from domestic wastewater. J Power Sources 2011;196:8293-300.

[159] Liu J, Qiao Y, Guo CX, Lim S, Song H, Li CM. Graphene/carbon cloth anode for highperformance mediatorless microbial fuel cells. Bioresour Technol 2012;114:275-80.

[160] Couret F, Vilar EO, Cavalcanti EB. Carbon fibre cloth as an electrode material: electrical conductivity and mass transfer. J Appl Electrochem 2002;32:1175-82.

[161] Chen CY, Chen TY, Chung YC. A comparison of bioelectricity in microbial fuel cells with aerobic and anaerobic anodes. Environ Technol 2014;35:286-93.

[162] Zhang LL. Carbon-based materials as supercapacitor electrodes. Chem Soc Rev 2009;38:252031.

[163] Zhang F, Xia X, Luo Y, Sun D, Call DF, Logan BE. Improving startup performance with carbon mesh anodes in separator electrode assembly microbial fuel cells. Bioresour Technol 2013;133:74-81.

[164] Cheng S, Logan BE. Ammonia treatment of carbon cloth anodes to enhance power generation of microbial fuel cells. Electrochem Commun 2007;9:492-6.

[165] Chaudhuri SK, Lovley DR. Electricity generation by direct oxidation of glucose in mediatorless microbial fuel cells. Nat Biotech 2003;21:1229-32. 
[166] Brownson DA, Varey SA, Hussain F, Haigh SJ, Banks CE. Electrochemical properties of CVD grown pristine graphene: monolayer-vs. quasi-graphene. Nanoscale 2014;6:1607-21.

[167] Lee C, Wei X, Kysar JW, Hone J. Measurement of the elastic properties and intrinsic strength of monolayer graphene. Science 2008;321:385-8.

[168] Mayorov AS, Gorbachev RV, Morozov SV, Britnell L, Jalil R, Ponomarenko LA, et al. Micrometer-scale ballistic transport in encapsulated graphene at room temperature. Nano Lett 2011;11:2396-9.

[169] Stoller MD, Park S, Zhu Y, An J, Ruoff RS. Graphene-based ultracapacitors. Nano Lett 2008;8:3498-502.

[170] Moser J, Barreiro A, Bachtold A. Current-induced cleaning of graphene. Appl Phys Lett 2007;91:No Pagination.

[171] Zhang Y, Mo G, Li X, Zhang W, Zhang J, Ye J, et al. A graphene modified anode to improve the performance of microbial fuel cells. J Power Sources 2011;196:5402-7.

[172] Xiao L, Damien J, Luo J, Jang HD, Huang J, He Z. Crumpled graphene particles for microbial fuel cell electrodes. J Power Sources 2012;208:187-92.

[173] Luo J, Jang HD, Sun T, Xiao L, He Z, Katsoulidis AP, et al. Compression and AggregationResistant Particles of Crumpled Soft Sheets. ACS Nano 2011;5:8943-9.

[174] Ren H, Tian H, Gardner CL, Ren TL, Chae J. A miniaturized microbial fuel cell with threedimensional graphene macroporous scaffold anode demonstrating a record power density of over $10,000 \mathrm{~W}$ m(-3). Nanoscale 2016;8:3539-47.

[175] Ferrari AC. Raman spectroscopy of graphene and graphite: Disorder, electron-phonon coupling, doping and nonadiabatic effects. Solid State Commun 2007;143:47-57.

[176] Novoselov KS, Fal V, Colombo L, Gellert P, Schwab M, Kim K. A roadmap for graphene. Nature 2012;490:192-200.

[177] Aqel A, El-Nour KMMA, Ammar RAA, Al-Warthan A. Carbon nanotubes, science and technology part (I) structure, synthesis and characterisation. Arab J Chem 2012;5:1-23.

[178] Terrones M. Carbon nanotubes: synthesis and properties, electronic devices and other emerging applications. Int Mater Rev 2013;49:325-7.

[179] Komarov F, Mironov A. Carbon nanotubes: present and future. Phys Chem Solid State 2004;5:411-29.

[180] Collins PG, Bradley K, Ishigami M, Zettl A. Extreme Oxygen Sensitivity of Electronic Properties of Carbon Nanotubes. Science 2000;287:1801-04.

[181] Banks CE, Davies TJ, Wildgoose GG, Compton RG. Electrocatalysis at graphite and carbon nanotube modified electrodes: edge-plane sites and tube ends are the reactive sites. Chem Comm 2005:829-41.

[182] Peng L, You S-J, Wang J-Y. Carbon nanotubes as electrode modifier promoting direct electron transfer from Shewanella oneidensis. Biosens Bioelectron 2010;25:1248-51.

[183] Wang H, Wu Z, Plaseied A, Jenkins P, Simpson L, Engtrakul C, et al. Carbon nanotube modified air-cathodes for electricity production in microbial fuel cells. J Power Sources 2011;196:7465-9.

[184] Thepsuparungsikul N, Ng TC, Lefebvre O, Ng HY. Different types of carbon nanotube-based anodes to improve microbial fuel cell performance. Water Sci Technol 2014;69:1900-10.

[185] Tender LM, Reimers CE, Stecher HA, Holmes DE, Bond DR, Lowy DA, et al. Harnessing microbially generated power on the seafloor. Nat Biotechnol 2002;20:821-5.

[186] Reimers C, Girguis P, Stecher H, Tender L, Ryckelynck N, Whaling P. Microbial fuel cell energy from an ocean cold seep. Geobiology 2006;4:123-36.

[187] Donovan C, Dewan A, Heo D, Beyenal H. Batteryless, wireless sensor powered by a sediment microbial fuel cell. Environ Sci Technol 2008;42:8591-6.

[188] ter Heijne A, Hamelers HVM, Saakes M, Buisman CJN. Performance of non-porous graphite and titanium-based anodes in microbial fuel cells. Electrochim Acta 2008;53:5697-703.

[189] Baudler A, Schmidt I, Langner M, Greiner A, Schröder U. Does it have to be carbon? Metal anodes in microbial fuel cells and related bioelectrochemical systems. Energ Environ Sci 2015;8:2048-55.

[190] Grass G, Rensing C, Solioz M. Metallic copper as an antimicrobial surface. Appl Environ Microbiol 2011;77:1541-7. 
[191] Schierholz J, Lucas L, Rump A, Pulverer G. Efficacy of silver-coated medical devices. J Hosp Infect 1998;40:257-62.

[192] Slate AJ, Wickens DJ, El Mohtadi M, Dempsey-Hibbert N, West G, Banks CE, et al. Antimicrobial activity of Ti-ZrN/Ag coatings for use in biomaterial applications. Sci Rep 2018;8:1497.

[193] Thieme M, Scharnweber D, Drechsler L, Heiser C, Adolphi B, Weiss A. Surface analytical characterization of chromium-stabilized protecting oxide layers on stainless steel referring to activity buildup. J Nucl Mater 1992;189:303-17.

[194] Richter H, McCarthy K, Nevin KP, Johnson JP, Rotello VM, Lovley DR. Electricity Generation by Geobacter sulfurreducens Attached to Gold Electrodes. Langmuir 2008;24:4376-9.

[195] Coppi MV, Leang C, Sandler SJ, Lovley DR. Development of a Genetic System for Geobacter sulfurreducens. Appl Environ Microbiol 2001;67:3180-7.

[196] Crittenden SR, Sund CJ, Sumner JJ. Mediating electron transfer from bacteria to a gold electrode via a self-assembled monolayer. Langmuir 2006;22:9473-6.

[197] Holmes DE, Chaudhuri SK, Nevin KP, Mehta T, Methé BA, Liu A, et al. Microarray and genetic analysis of electron transfer to electrodes in Geobacter sulfurreducens. Environ Microbiol 2006;8:1805-15.

[198] Huang L, Regan JM, Quan X. Electron transfer mechanisms, new applications, and performance of biocathode microbial fuel cells. Bioresour Technol 2011;102:316-23.

[199] Lovley DR. Electromicrobiology. Annu Rev Microbiol 2012;66:391-409.

[200] Kumar A, Katuri K, Lens P, Leech D. Does bioelectrochemical cell configuration and anode potential affect biofilm response?. Biochem Soc Trans 2012;40:1308-14.

[201] Ieropoulos I, Melhuish C, Greenman J. In: Energetically Autonomous Robots. Proceedings of the 8th Intelligent Autonomous Systems Conference: Amsterdam, The Netherlands; 2004, p. 128-35. [202] Reguera G, McCarthy KD, Mehta T, Nicoll JS, Tuominen MT, Lovley DR. Extracellular electron transfer via microbial nanowires. Nature 2005;435:1098-101.

[203] Conrad Jacinta C, Gibiansky Maxsim L, Jin F, Gordon Vernita D, Motto Dominick A, Mathewson Margie A, et al. Flagella and Pili-Mediated Near-Surface Single-Cell Motility

Mechanisms in P. aeruginosa. Biophys J 2011;100:1608-16.

[204] Shi W, Sun H. Type IV Pilus-Dependent Motility and Its Possible Role in Bacterial Pathogenesis. Infect Immun 2002;70:1-4.

[205] Reguera G, Nevin KP, Nicoll JS, Covalla SF, Woodard TL, Lovley DR. Biofilm and nanowire production leads to increased current in Geobacter sulfurreducens fuel cells. Appl Environ Microbiol 2006;72:7345-8.

[206] Badalamenti JP, Krajmalnik-Brown R, Torres CI. Generation of high current densities by pure cultures of anode-respiring Geoalkalibacter spp. under alkaline and saline conditions in microbial electrochemical cells. mBio 2013;4:e00144-13.

[207] Malvankar NS, Tuominen MT, Lovley DR. Biofilm conductivity is a decisive variable for highcurrent-density Geobacter sulfurreducens microbial fuel cells. Energ Environ Sci 2012;5:5790-7.

[208] Tan Y, Adhikari RY, Malvankar NS, Ward JE, Nevin KP, Woodard TL, et al. The Low Conductivity of Geobacter uraniireducens Pili Suggests a Diversity of Extracellular Electron Transfer Mechanisms in the Genus Geobacter. Front Microbiol 2016;7:No Pagination.

[209] Methé BA, Nelson KE, Eisen JA, Paulsen IT, Nelson W, Heidelberg JF, et al. Genome of Geobacter sulfurreducens: metal reduction in subsurface environments. Science 2003;302:1967-69.

[210] Adhikari RY, Malvankar NS, Tuominen MT, Lovley DR. Conductivity of individual Geobacter pili. RSC Adv 2016;6:8354-7.

[211] Galushko AS, Schink B. Oxidation of acetate through reactions of the citric acid cycle by Geobacter sulfurreducens in pure culture and in syntrophic coculture. Arch Microbiol 2000;174:31421.

[212] Childers SE, Ciufo S, Lovley DR. Geobacter metallireducens accesses insoluble Fe(iii) oxide by chemotaxis. Nature 2002;416:767-9.

[213] Friman H, Schechter A, Ioffe Y, Nitzan Y, Cahan R. Current production in a microbial fuel cell using a pure culture of Cupriavidus basilensis growing in acetate or phenol as a carbon source. Microb Biotechnol 2013;6:425-34. 
[214] Lovley DR, Phillips EJ. Novel mode of microbial energy metabolism: organic carbon oxidation coupled to dissimilatory reduction of iron or manganese. Appl Environ Microbiol 1988;54:1472-80.

[215] Yue H, Khoshtariya D, Waldeck DH, Grochol J, Hildebrandt P, Murgida DH. On the Electron Transfer Mechanism Between Cytochrome c and Metal Electrodes. Evidence for Dynamic Control at Short Distances. J Chem Biol Phys Sci 2006;110:19906-13.

[216] Ow YP, Green DR, Hao Z, Mak TW. Cytochrome c: functions beyond respiration. Nat Rev Mol Cell Biol 2008;9:532-42.

[217] Smith JA, Tremblay PL, Shrestha PM, Snoeyenbos-West OL, Franks AE, Nevin KP, et al. Going wireless: $\mathrm{Fe}(\mathrm{III})$ oxide reduction without pili by Geobacter sulfurreducens strain JS-1. Appl Environ Microbiol 2014;80:4331-40.

[218] Nevin KP, Kim B-C, Glaven RH, Johnson JP, Woodard TL, Methé BA, et al. Anode Biofilm Transcriptomics Reveals Outer Surface Components Essential for High Density Current Production in Geobacter sulfurreducens Fuel Cells. PLoS one 2009;4:e5628.

[219] Mehta T, Coppi MV, Childers SE, Lovley DR. Outer Membrane c-Type Cytochromes Required for Fe(III) and Mn(IV) Oxide Reduction in Geobacter sulfurreducens. Appl Environ Microbiol 2005;71:8634-41.

[220] Leang C, Coppi MV, Lovley DR. OmcB, a c-type polyheme cytochrome, involved in Fe(III) reduction in Geobacter sulfurreducens. J Bacteriol 2003;185:2096-103.

[221] Kim BC, Qian X, Leang C, Coppi MV, Lovley DR. Two putative c-type multiheme cytochromes required for the expression of $\mathrm{OmcB}$, an outer membrane protein essential for optimal $\mathrm{Fe}(\mathrm{III})$ reduction in Geobacter sulfurreducens. J Bacteriol 2006;188:3138-42.

[222] Qian X, Reguera G, Mester T, Lovley DR. Evidence that OmcB and OmpB of Geobacter sulfurreducens are outer membrane surface proteins. FEMS Microbiol Lett 2007;277:21-7.

[223] Lovley DR. Bug juice: harvesting electricity with microorganisms. Nat Rev Micro 2006;4:497508.

[224] Lovley DR. Powering microbes with electricity: direct electron transfer from electrodes to microbes. Environ Microbiol Rep 2011;3:27-35.

[225] Liu G, Chater KF, Chandra G, Niu G, Tan H. Molecular regulation of antibiotic biosynthesis in streptomyces. Microbiol Mol Biol Rev 2013;77:112-43.

[226] Bibb MJ. Regulation of secondary metabolism in streptomycetes. Curr Opin Microbiol 2005;8:208-15.

[227] Velasquez-Orta SB, Head IM, Curtis TP, Scott K, Lloyd JR, von Canstein H. The effect of flavin electron shuttles in microbial fuel cells current production. Appl Microbiol Biotechnol 2010;85:1373-81.

[228] Bennetto HP, Stirling JL, Tanaka K, Vega CA. Anodic reactions in microbial fuel cells. Biotechnol Bioeng 1983;25:559-68.

[229] Roller SD. Electron-transfer coupling in microbial fuel cells: 1. comparison of redox-mediator reduction rates and respiratory rates of bacteria. J Chem Technol Biotechnol 1984;34:3-12.

[230] Newman DK, Kolter R. A role for excreted quinones in extracellular electron transfer. Nature 2000;405:94-7.

[231] Sund CJ, McMasters S, Crittenden SR, Harrell LE, Sumner JJ. Effect of electron mediators on current generation and fermentation in a microbial fuel cell. Appl Microbiol Biotechnol 2007;76:5618.

[232] Lee Y, Bae S, Moon C, Lee W. Flavin mononucleotide mediated microbial fuel cell in the presence of Shewanella putrefaciens CN32 and iron-bearing mineral. Biotechnol Bioprocess Eng 2015;20:894-900.

[233] Marsili E, Baron DB, Shikhare ID, Coursolle D, Gralnick JA, Bond DR. Shewanella secretes flavins that mediate extracellular electron transfer. Proc Natl Acad Sci U S A 2008;105:3968-73. [234] Qiao Y, Li CM, Bao S-J, Lu Z, Hong Y. Direct electrochemistry and electrocatalytic mechanism of evolved Escherichia coli cells in microbial fuel cells. Chem Comm 2008;0:1290-2. [235] Shen H-B, Yong X-Y, Chen Y-L, Liao Z-H, Si R-W, Zhou J, et al. Enhanced bioelectricity generation by improving pyocyanin production and membrane permeability through sophorolipid addition in Pseudomonas aeruginosa-inoculated microbial fuel cells. Bioresour Technol 2014;167:490-4. 
[236] El-Fouly MZ, Sharaf AM, Shahin AAM, El-Bialy HA, Omara AMA. Biosynthesis of pyocyanin pigment by Pseudomonas aeruginosa. J Radiat Res Appl Sci 2015;8:36-48.

[237] Baron SS, Rowe JJ. Antibiotic action of pyocyanin. Antimicrob Agents Chemother 1981;20:814-20.

[238] Kerr J, Taylor G, Rutman A, Høiby N, Cole P, Wilson R. Pseudomonas aeruginosa pyocyanin and 1-hydroxyphenazine inhibit fungal growth. J Clin Pathol 1999;52:385-7.

[239] Jayaseelan S, Ramaswamy D, Dharmaraj S. Pyocyanin: production, applications, challenges and new insights. World J Microbiol Biotechnol 2014;30:1159-68.

[240] Rabaey K, Boon N, Höfte M, Verstraete W. Microbial phenazine production enhances electron transfer in biofuel cells. Environ Sci Technol 2005;39:3401-8.

[241] Wang Y, Kern SE, Newman DK. Endogenous phenazine antibiotics promote anaerobic survival of Pseudomonas aeruginosa via extracellular electron transfer. J Bacteriol 2010;192:365-9.

[242] Watanabe K, Manefield M, Lee M, Kouzuma A. Electron shuttles in biotechnology. Curr Opin Biotechnol 2009;20:633-41.

[243] Dietrich LE, Price-Whelan A, Petersen A, Whiteley M, Newman DK. The phenazine pyocyanin is a terminal signalling factor in the quorum sensing network of Pseudomonas aeruginosa. Mol Microbiol 2006;61:1308-21.

[244] Williams P, Cámara M. Quorum sensing and environmental adaptation in Pseudomonas aeruginosa: a tale of regulatory networks and multifunctional signal molecules. Curr Opin Microbiol 2009;12:182-91.

[245] Diggle SP, Winzer K, Chhabra SR, Worrall KE, Cámara M, Williams P. The Pseudomonas aeruginosa quinolone signal molecule overcomes the cell density-dependency of the quorum sensing hierarchy, regulates rhl-dependent genes at the onset of stationary phase and can be produced in the absence of LasR. Mol Microbiol 2003;50:29-43.

[246] Franks AE, Nevin KP. Microbial fuel cells, a current review. Energies 2010;3:899-919.

[247] Wu C-H, I Y-P, Chiu Y-H, Lin C-W. Enhancement of power generation by toluene

biodegradation in a microbial fuel cell in the presence of pyocyanin. J Taiwan Inst Chem Eng 2014;45:2319-24.

[248] Ishii Si, Watanabe K, Yabuki S, Logan BE, Sekiguchi Y. Comparison of Electrode Reduction Activities of Geobacter sulfurreducens and an Enriched Consortium in an Air-Cathode Microbial Fuel Cell. Appl Environ Microbiol 2008;74:7348-55.

[249] Fernández de Dios MÁ, del Campo AG, Fernández FJ, Rodrigo M, Pazos M, Sanromán MÁ. Bacterial-fungal interactions enhance power generation in microbial fuel cells and drive dye decolourisation by an ex situ and in situ electro-Fenton process. Bioresour Technol 2013;148:39-46. [250] Li C, Lesnik KL, Fan Y, Liu H. Redox Conductivity of Current-Producing Mixed Species Biofilms. PLoS One 2016;11:No Pagination.

[251] Bennetto H. Electricity generation by microorganisms. Biotechnology education. 1990;1:163-8. [252] Ahmed J, Yuan Y, Zhou L, Kim S. Carbon supported cobalt oxide nanoparticles-iron phthalocyanine as alternative cathode catalyst for oxygen reduction in microbial fuel cells. J Power Sources 2012;208:170-5.

[253] Lu G, Zhu Y, Lu L, Xu K, Wang H, Jin Y, et al. Iron-rich nanoparticle encapsulated, nitrogen doped porous carbon materials as efficient cathode electrocatalyst for microbial fuel cells. J Power Sources 2016;315:302-7.

[254] Ma M, You S, Gong X, Dai Y, Zou J, Fu H. Silver/iron oxide/graphitic carbon composites as bacteriostatic catalysts for enhancing oxygen reduction in microbial fuel cells. J Power Sources 2015;283:74-83.

[255] Li D, Qu Y, Liu J, He W, Wang H, Feng Y. Using ammonium bicarbonate as pore former in activated carbon catalyst layer to enhance performance of air cathode microbial fuel cell. J Power Sources 2014;272:909-14.

[256] Mohapatra M, Rout K, Gupta SK, Singh P, Anand S, Mishra BK. Facile synthesis of additiveassisted nano goethite powder and its application for fluoride remediation. J Nanopart Res 2010;12:681-6.

[257] He Z. Development of Microbial Fuel Cells Needs To Go beyond "Power Density". ACS Energy Lett 2017;2:700-2. 
[258] Pant D, Singh A, Van Bogaert G, Irving Olsen S, Singh Nigam P, Diels L, et al. Bioelectrochemical systems (BES) for sustainable energy production and product recovery from organic wastes and industrial wastewaters. RSC Adv 2012;2:1248-63.

[259] Sharma M, Bajracharya S, Gildemyn S, Patil SA, Alvarez-Gallego Y, Pant D, et al. A critical revisit of the key parameters used to describe microbial electrochemical systems. Electrochim Acta 2014;140:191-208.

[260] Ge Z, Li J, Xiao L, Tong Y, He Z. Recovery of electrical energy in microbial fuel cells: brief review. Environ Sci Technol Lett 2013;1:137-41.

[261] Layton BE. A comparison of energy densities of prevalent energy sources in units of joules per cubic meter. Int J Green Energy 2008;5:438-55.

[262] Kim KY, Yang WL, Evans PJ, Logan BE. Continuous treatment of high strength wastewaters using air-cathode microbial fuel cells. Bioresour Technol 2016;221:96-101.

[263] Jung S, Regan JM. Comparison of anode bacterial communities and performance in microbial fuel cells with different electron donors. Appl Microbiol Biotechnol 2007;77:393-402.

[264] Rahimnejad M, Mokhtarian N, Najafpour G, Daud W, Ghoreyshi A. Low voltage power generation in abiofuel cell using anaerobic cultures. World Appl Sci J 2009;6:1585-8.

[265] Bond DR, Holmes DE, Tender LM, Lovley DR. Electrode-reducing microorganisms that harvest energy from marine sediments. Science 2002;295:483-5.

[266] Logan BE, Murano C, Scott K, Gray ND, Head IM. Electricity generation from cysteine in a microbial fuel cell. Water Res 2005;39:942-52.

[267] Kim JR, Jung SH, Regan JM, Logan BE. Electricity generation and microbial community analysis of alcohol powered microbial fuel cells. Bioresour Technol 2007;98:2568-77.

[268] Rahimnejad M, Ghoreyshi AA, Najafpour G, Jafary T. Power generation from organic substrate in batch and continuous flow microbial fuel cell operations. Appl Energy 2011;88:3999-4004.

[269] Zhang T, Zeng Y, Chen S, Ai X, Yang H. Improved performances of E. coli-catalyzed microbial fuel cells with composite graphite/PTFE anodes. Electrochem Commun 2007;9:349-53.

[270] Hassan SHA, Kim YS, Oh S-E. Power generation from cellulose using mixed and pure cultures of cellulose-degrading bacteria in a microbial fuel cell. Enzyme Microb Technol 2012;51:269-73.

[271] Zou Y, Xiang C, Yang L, Sun L-X, Xu F, Cao Z. A mediatorless microbial fuel cell using polypyrrole coated carbon nanotubes composite as anode material. Int J Hydrogen Energy 2008;33:4856-62.

[272] Rahimnejad M, Ghoreyshi AA, Najafpour G. Effect of mass transfer on performance of microbial fuel cell. In: Mass Transfer in Chemical Engineering Processes, editors. Markoš J, InTechOpen; 2011: p. 233-50.

[273] Antonopoulou G, Stamatelatou K, Bebelis S, Lyberatos G. Electricity generation from synthetic substrates and cheese whey using a two chamber microbial fuel cell. Biochem Eng J 2010;50:10-5. [274] Rabaey K, Lissens G, Siciliano SD, Verstraete W. A microbial fuel cell capable of converting glucose to electricity at high rate and efficiency. Biotechnol Lett 2003;25:1531-5.

[275] Logan B, Cheng S, Watson V, Estadt G. Graphite Fiber Brush Anodes for Increased Power Production in Air-Cathode Microbial Fuel Cells. Environ Sci Technol 2007;41:3341-6.

[276] Hou J, Liu Z, Zhang P. A new method for fabrication of graphene/polyaniline nanocomplex modified microbial fuel cell anodes. J Power Sources 2013;224:139-44.

[277] Wang H, Wang G, Ling Y, Qian F, Song Y, Lu X, et al. High power density microbial fuel cell with flexible 3D graphene-nickel foam as anode. Nanoscale 2013;5:10283-90.

[278] He Z, Liu J, Qiao Y, Li CM, Tan TTY. Architecture Engineering of Hierarchically Porous Chitosan/Vacuum-Stripped Graphene Scaffold as Bioanode for High Performance Microbial Fuel Cell. Nano Lett 2012;12:4738-41.

[279] Xie X, Yu G, Liu N, Bao Z, Criddle CS, Cui Y. Graphene-sponges as high-performance lowcost anodes for microbial fuel cells. Energ Environ Sci 2012;5:6862-6.

[280] Zhang Y, Mo G, Li X, Ye J. Iron tetrasulfophthalocyanine functionalized graphene as a platinum-free cathodic catalyst for efficient oxygen reduction in microbial fuel cells. J Power Sources 2012;197:93-6.

[281] Liu Y, Liu H, Wang C, Hou S-X, Yang N. Sustainable Energy Recovery in Wastewater Treatment by Microbial Fuel Cells: Stable Power Generation with Nitrogen-doped Graphene Cathode. Environ Sci Technol 2013;47:13889-95. 
[282] Zhao C, Wang Y, Shi F, Zhang J, Zhu JJ. High biocurrent generation in Shewanella-inoculated microbial fuel cells using ionic liquid functionalized graphene nanosheets as an anode. Chem Comm 2013;49:6668-70.

[283] Guo W, Cui Y, Song H, Sun J. Layer-by-layer construction of graphene-based microbial fuel cell for improved power generation and methyl orange removal. Bioprocess Biosyst Eng

2014;37:1749-58.

[284] Clauwaert P, Van Der Ha D, Boon N, Verbeken K, Verhaege M, Rabaey K, et al. Open air biocathode enables effective electricity generation with microbial fuel cells. Environ Sci Technol 2007;41:7564-9.

[285] Hou J, Liu Z, Li Y, Yang S, Zhou Y. A comparative study of graphene-coated stainless steel fiber felt and carbon cloth as anodes in MFCs. Bioprocess Biosyst Eng 2015;38:881-8.

[286] Najafabadi AT, Ng N, Gyenge E. Electrochemically exfoliated graphene anodes with enhanced biocurrent production in single-chamber air-breathing microbial fuel cells. Biosens Bioelectron 2016;81:103-10.

[287] Yuan Y, Zhou S, Zhao B, Zhuang L, Wang Y. Microbially-reduced graphene scaffolds to facilitate extracellular electron transfer in microbial fuel cells. Bioresour Technol 2012;116:453-8.

[288] Lv Z, Chen Y, Wei H, Li F, Hu Y, Wei C, et al. One-step electrosynthesis of polypyrrole/graphene oxide composites for microbial fuel cell application. Electrochim Acta 2013;111:366-73.

[289] Wen Q, Wang S, Yan J, Cong L, Pan Z, Ren Y, et al. MnO 2-graphene hybrid as an alternative cathodic catalyst to platinum in microbial fuel cells. J Power Sources 2012;216:187-91.

[290] Mehdinia A, Ziaei E, Jabbari A. Facile microwave-assisted synthesized reduced graphene oxide/tin oxide nanocomposite and using as anode material of microbial fuel cell to improve power generation. Int J Hydrogen Energy 2014;39:10724-30.

[291] Tsai H-Y, Wu C-C, Lee C-Y, Shih EP. Microbial fuel cell performance of multiwall carbon nanotubes on carbon cloth as electrodes. J Power Sources 2009;194:199-205.

[292] Zhao Ce, Wang WJ, Sun D, Wang X, Zhang JR, Zhu JJ. Nanostructured Graphene/TiO2 Hybrids as High-Performance Anodes for Microbial Fuel Cells. Chem Eur J 2014;20:7091-7.

[293] Kumar GG, Hashmi S, Karthikeyan C, GhavamiNejad A, Vatankhah-Varnoosfaderani M, Stadler FJ. Graphene oxide/carbon nanotube composite hydrogels-versatile materials for microbial fuel cell applications. Macromol Rapid Commun 2014;35:1861-5.

[294] Sharaf OZ, Orhan MF. An overview of fuel cell technology: Fundamentals and applications. Renew Sust Energ Rev 2014;32:810-53.

[295] Ter Heijne A, Liu F, van Rijnsoever LS, Saakes M, Hamelers HVM, Buisman CJN.

Performance of a scaled-up Microbial Fuel Cell with iron reduction as the cathode reaction. J Power Sources 2011;196:7572-7.

[296] Shoener B, Bradley I, Cusick R, Guest J. Energy positive domestic wastewater treatment: the roles of anaerobic and phototrophic technologies. Environ Sci Process Impacts 2014;16:1204-22. [297] Mazzoldi F. Creating Life Through Generative Design. TechCrunch; 2016. 
Table 1: Overview of the state of the current literature of MFC performance with respect to the variable electrochemical-biology mechanisms and carbon-based electrodes. The best output by an MFC known to date is, $5.61 \mathrm{w} \mathrm{m}^{-2}\left(11,200 \mathrm{~W} \mathrm{~m}^{3}\right)$ this can be compared to the US national average of solar power which is estimated to be between $100 \mathrm{~W} \mathrm{~m}^{-2}$ and $150 \mathrm{~W} \mathrm{~m}^{-2}[174,261]$. Note, that in regards to the energy output, the units/benchmarking are not consistent therefore comparison between MFCs is difficult.

\begin{tabular}{|c|c|c|c|c|c|c|}
\hline Anode Material & Cathode material & $\begin{array}{c}\text { Microbial } \\
\text { Composition }\end{array}$ & Fuel / Substrate & $\begin{array}{l}\text { Suggested } \\
\text { Mechanism }\end{array}$ & Energy Output & Reference \\
\hline $\begin{array}{c}\text { 3D few-layer } \\
\text { graphene macroporous } \\
\text { scaffolds }\end{array}$ & $\begin{array}{l}\text { Glass slide coated with a } \\
\text { layer of } \mathrm{Cr} / \mathrm{Au} \text { or } \mathrm{Ti} / \mathrm{Pt}\end{array}$ & $\begin{array}{l}\text { Mixed community } \\
\text { - Geobacter spp., } \\
\text { enriched }\end{array}$ & - & $\begin{array}{l}\text { Cytochrome c } \\
\text { activity }\end{array}$ & $11,2000 \mathrm{~W} \mathrm{~m}^{-3}$ & {$[174]$} \\
\hline $\begin{array}{l}\text { 2D monolayer } \\
\text { graphene sheet }\end{array}$ & $\begin{array}{l}\text { Glass slide coated with a } \\
\text { layer of } \mathrm{Cr} / \mathrm{Au} \text { or } \mathrm{Ti} / \mathrm{Pt}\end{array}$ & $\begin{array}{l}\text { Mixed community } \\
\text { - Geobacter spp., } \\
\text { enriched }\end{array}$ & - & $\begin{array}{l}\text { Cytochrome c } \\
\text { activity }\end{array}$ & $8,840 \mathrm{~W} \mathrm{~m}^{-3}$ & {$[174]$} \\
\hline Carbon felt & $\begin{array}{l}\text { Activated carbon, carbon } \\
\text { black and } \\
\text { poly(vinylideneflouride) } \\
\text { binder }\end{array}$ & $\begin{array}{l}\text { Aerobic mixed } \\
\text { community }\end{array}$ & $\begin{array}{l}\text { 'High strength' } \\
\text { swine wastewater }\end{array}$ & - & $750 \pm 70 \mathrm{~mW} \mathrm{~m}^{-2}$ & [262] \\
\hline Carbon felt & Graphite felt & $\begin{array}{l}\text { Anaerobic mixed } \\
\text { community }\end{array}$ & $\begin{array}{l}\text { Sludge from } \\
\text { domestic } \\
\text { wastewater }\end{array}$ & - & $7.07 \mathrm{~mW} \mathrm{~m}^{-2}$ & {$[161]$} \\
\hline Carbon felt & Graphite felt & $\begin{array}{l}\text { Anaerobic mixed } \\
\text { community }\end{array}$ & $\begin{array}{l}\text { Sludge from } \\
\text { domestic } \\
\text { wastewater }\end{array}$ & - & $2.34 \mathrm{~mW} \mathrm{~m}^{-2}$ & {$[161]$} \\
\hline
\end{tabular}




\begin{tabular}{|c|c|c|c|c|c|}
\hline Carbon cloth & Carbon cloth/carbon felt & Mixed community & - & $\begin{array}{l}\text { Direct - nanowires } \\
\text { and c cytochrome }\end{array}$ & $3.5 \mathrm{~A} \mathrm{~m}^{2}$ \\
\hline Graphite felt & Graphite felt & R. ferrireducens & - & $\begin{array}{l}\text { Direct contact } \\
\text { mediated - } \\
\text { nanowires }\end{array}$ & $\begin{array}{c}0.57 \mathrm{~mA} \mathrm{~m}^{2} / 620 \\
\mathrm{mV}\end{array}$ \\
\hline Graphite foam & Graphite foam & R. ferrireducens & - & $\begin{array}{l}\text { Direct contact } \\
\text { mediated - } \\
\text { nanowires }\end{array}$ & $\begin{array}{c}74 \mathrm{~mA} \mathrm{~m}^{2} / 445 \\
\mathrm{mV}\end{array}$ \\
\hline $\begin{array}{l}\text { Multilayer graphene } \\
\text { coating on stainless } \\
\text { steel electrode }\end{array}$ & Carbon paper & E. coli & Glucose & - & $2668 \mathrm{~mW} \mathrm{~m}^{-2}$ \\
\hline $\begin{array}{l}\text { Reduced graphene } \\
\text { oxide (particles) }\end{array}$ & Carbon cloth & Mixed community & $\begin{array}{l}\text { Anaerobic sludge } \\
\text { from wastewater }\end{array}$ & - & $3.6 \mathrm{~W} \mathrm{~m}^{-3}$ \\
\hline $\begin{array}{l}\text { Activated carbon } \\
\text { modified electrode }\end{array}$ & Carbon cloth & Mixed community & $\begin{array}{l}\text { Anaerobic sludge } \\
\text { from wastewater }\end{array}$ & - & $1.7 \mathrm{~W} \mathrm{~m}^{-3}$ \\
\hline $\begin{array}{l}\text { Reduced graphene } \\
\text { oxide (sheets) }\end{array}$ & Carbon cloth & Mixed community & $\begin{array}{l}\text { Anaerobic sludge } \\
\text { from wastewater }\end{array}$ & - & $2.7 \mathrm{~W} \mathrm{~m}^{-3}$ \\
\hline $\begin{array}{l}\text { Glassy carbon coated } \\
\text { with MWCNTs }\end{array}$ & Glassy carbon & $\begin{array}{l}\text { Shewanella } \\
\text { oneidensis }\end{array}$ & - & - & $9.70 \mu \mathrm{A} \mathrm{cm}{ }^{2}$ \\
\hline $\begin{array}{l}\text { MWCNTs with } \\
\text { hydroxyl groups }\end{array}$ & $\begin{array}{l}\text { Carbon cloth coated with } \\
\text { platinum }\end{array}$ & Mixed community & - & - & $167 \mathrm{~mW} \mathrm{~m}^{2}$ \\
\hline
\end{tabular}

Multilayer graphene coating on stainless

Reduced graphene oxide (particles)

Anaerobic sludge 


\begin{tabular}{|c|c|c|c|c|c|}
\hline Carbon paper & $\begin{array}{l}\text { carbon paper coated with } \\
\text { Pt catalyst }\left(0.35 \mathrm{mg} / \mathrm{cm}^{2}\right. \\
\quad ; 10 \% \mathrm{Pt}, \mathrm{E}-\mathrm{TEK})\end{array}$ & Geobacter spp,. & Glucose & - & $40.3 \pm 3.9 \mathrm{~mW} \mathrm{~m}^{-2}$ \\
\hline Graphite plate & Graphite plate & $\begin{array}{l}\text { Saccharomyces } \\
\text { cerevisiae }\end{array}$ & Glucose & - & $16 \mathrm{~mW} \mathrm{~m}^{-2}$ \\
\hline Carbon paper & $\begin{array}{l}\text { carbon paper coated with } \\
\text { Pt catalyst }\left(0.35 \mathrm{mg} / \mathrm{cm}^{2}\right. \\
\quad ; 10 \% \mathrm{Pt}, \mathrm{E}-\mathrm{TEK})\end{array}$ & G. sulfurreducens & Acetate & - & $48.4 \pm 0.3 \mathrm{~mW} \mathrm{~m}^{-2}$ \\
\hline Carbon paper & $\begin{array}{l}\text { carbon paper coated with } \\
\text { Pt catalyst }\left(0.35 \mathrm{mg} \mathrm{cm}^{-2}\right. \\
\quad ; 10 \% \mathrm{Pt}, \mathrm{E}-\mathrm{TEK})\end{array}$ & Geobacter spp,. & Lactate & - & $52 \pm 4.75 \mathrm{~mW} \mathrm{~m}^{-2}$ \\
\hline Graphite & Graphite & $\begin{array}{c}\text { Deltaproteo } \\
\text { bacterium }\end{array}$ & $\begin{array}{l}\text { Marine sediment } \\
\text { in acetate }\end{array}$ & - & $14 \mathrm{~mW} \mathrm{~m}^{-2}$ \\
\hline Carbon paper & $\begin{array}{l}\text { Carbon paper containing } \\
\text { either } 0.35 \mathrm{mg} / \mathrm{cm}^{2} \text { of } \mathrm{Pt} \text {, } \\
\text { or } 0.50 \mathrm{mg} \mathrm{cm}^{-2} \mathrm{Pt} / \mathrm{Ru} \\
(1: 1 \mathrm{molar} \text { ratio })\end{array}$ & $\begin{array}{l}\text { Gammaproteo and } \\
\text { Shewanella affinis }\end{array}$ & Cyctenin & - & $36 \mathrm{~mW} \mathrm{~m}^{-2}$ \\
\hline Carbon paper & $\begin{array}{l}\text { Carbon paper containing } \\
\text { a Pt catalyst } \\
\left(0.35 \mathrm{mg} / \mathrm{cm}^{2} ; 10 \% \mathrm{Pt}\right. \\
\text { E-Tek, NJ })\end{array}$ & Betaproteobacteria & Ethanol & - & $40 \pm 2 \mathrm{~mW} \mathrm{~m}^{-2}$ \\
\hline
\end{tabular}
$0.50 \mathrm{mg} \mathrm{cm}^{-2} \mathrm{Pt} / \mathrm{R}$
$(1: 1 \mathrm{molar}$ ratio $)$

arbon paper containing

$$
\begin{gathered}
\text { a Pt catalyst } \\
\left(0.35 \mathrm{mg} / \mathrm{cm}^{2} ; 10 \% \mathrm{Pt} ;\right. \\
\text { E-Tek, NJ })
\end{gathered}
$$




\begin{tabular}{|c|c|c|c|c|c|}
\hline $\begin{array}{c}\text { Graphite with neutral } \\
\text { red (NR) }\end{array}$ & $\begin{array}{l}\text { Graphite coated with a } 1 \\
\text { mm thick porcelain } \\
\text { septum made from } 100 \% \\
\text { kaolin }\end{array}$ & E. coli & Sewage sludge & - & $152 \mathrm{~mW} \mathrm{~m}^{-2}$ \\
\hline Graphite with $\mathrm{Mn}^{4+}$ & $\begin{array}{l}\text { Graphite coated with a } 1 \\
\text { mm thick porcelain } \\
\text { septum made from } 100 \% \\
\text { kaolin }\end{array}$ & E. coli & Sewage sludge & - & $91 \mathrm{~mW} \mathrm{~m}^{-2}$ \\
\hline Graphite plates & Graphite plates & Mixed community & Glucose & - & $283 \mathrm{Mw} \mathrm{m}^{-2}$ \\
\hline $\begin{array}{l}\text { Composite electrode } \\
\text { (graphite/PTFE) }\end{array}$ & $\begin{array}{c}\text { Graphite air-cathode with } \\
\text { a Pt/C catalyst layer } \\
(40 \mathrm{wt} \% \text { of } \mathrm{Pt})\end{array}$ & E. coli & Glucose & - & $760 \mathrm{~mW} \mathrm{~m}^{-2}$ \\
\hline $\begin{array}{l}\text { Non-wet-proof carbon } \\
\text { paper }\end{array}$ & $\begin{array}{c}\text { Non-wet-proof carbon } \\
\text { paper }\end{array}$ & Mixed community & Cellulose & - & $188 \mathrm{~mW} \mathrm{~m}{ }^{2}$ \\
\hline $\begin{array}{l}\text { Carbon paper with } \\
\text { polypyrrole coated- } \\
\text { CNTs }\end{array}$ & $\begin{array}{c}\text { Non-wet-proof carbon } \\
\text { paper }\end{array}$ & E. coli & Glucose & - & $228 \mathrm{~mW} \mathrm{~m}^{-2}$ \\
\hline $\begin{array}{l}\text { Teflon treated carbon } \\
\text { fibre paper }\end{array}$ & Graphite plate & Mixed community & Glucose & - & $15.2 \mathrm{~mW} \mathrm{~m}^{-2}$ \\
\hline $\begin{array}{l}\text { Teflon treated carbon } \\
\text { fibre paper }\end{array}$ & $\begin{array}{l}\text { Carbon cloth coated with } \\
\text { a Pt catalyst (ETEK, } 0.5 \\
\left.\qquad \mathrm{mg} \mathrm{cm}^{-2}\right)\end{array}$ & Mixed community & Lactose & - & $17.2 \mathrm{~mW} \mathrm{~m}^{-2}$ \\
\hline
\end{tabular}




\begin{tabular}{|c|c|c|c|c|c|}
\hline Graphite & Graphite & Mixed community & Glucose & - & $3.6 \mathrm{~W} \mathrm{~m}^{-2}$ \\
\hline $\begin{array}{l}\text { Graphite fibre brush } \\
\text { anodes }\end{array}$ & $\begin{array}{l}30 \mathrm{wt} \% \text { wet-proofed } \\
\text { carbon cloth (type B-1B, } \\
\text { E-TEK) with platinum } \\
\left(0.5 \mathrm{mg} \mathrm{cm}^{-2}\right)\end{array}$ & Mixed community & $\begin{array}{c}1 \mathrm{~g} \mathrm{~L}^{-1} \text { acetate in } \\
50 \mathrm{mM} \text { phosphate } \\
\text { buffer }\end{array}$ & - & $1430 \mathrm{~mW} \mathrm{~m}^{-2}$ \\
\hline $\begin{array}{l}\text { Reduced graphene } \\
\text { oxide and polyaniline } \\
\text { nanofibers coated onto } \\
\text { carbon cloth }\end{array}$ & Carbon felt & Mixed community & Anaerobic sludge & - & $1390 \mathrm{~mW} \mathrm{~m}^{-2}$ \\
\hline $\begin{array}{l}\text { Reduced graphene } \\
\text { oxide coated onto } \\
\text { carbon cloth }\end{array}$ & Carbon felt & Mixed community & Anaerobic sludge & - & $1003 \mathrm{~mW} \mathrm{~m}^{-2}$ \\
\hline Carbon cloth & Carbon felt & Mixed community & Anaerobic sludge & - & $468 \mathrm{~mW} \mathrm{~m}^{-2}$ \\
\hline $\begin{array}{l}\text { Three-dimensional } \\
\text { (3D) reduced } \\
\text { graphene oxide-nickel } \\
\text { foam anode }\end{array}$ & Carbon cloth & $\begin{array}{c}\text { Shewanella } \\
\text { oneidensis MR-1 }\end{array}$ & $\begin{array}{l}25 \mathrm{~mL} \text { solution of } \\
50 \mathrm{mM} \\
\text { ferricyanide in } \\
100 \mathrm{mM} \text { PBS }-\mathrm{pH} \\
7.4\end{array}$ & - & $661 \mathrm{~mW} \mathrm{~m}^{-3}$ \\
\hline $\begin{array}{l}\text { Hierarchically porous } \\
\text { chitosan/vacuum }\end{array}$ & Carbon cloth & P. aeruginosa & Glucose & $\begin{array}{c}\text { Endogenous } \\
\text { phenazine mediator }\end{array}$ & $1530 \mathrm{~mW} \mathrm{~m}^{-2}$ \\
\hline
\end{tabular}
chitosan/vacuum 
stripped graphene scaffold

Multilayer graphene sponge composite anode with stainless steel current collectors

Multilayer graphene with iron

tetrasulfophthalocyani ne (FeTsPc)

\section{Nitrogen-doped graphene}

1-(3-aminopropyl)-3methylimidazolium bromide

functionalized graphe ne nanosheets carbon cloth electrode coated with platinum catalyst

Mixed community

Waste water with glucose

Culture medium (PBS, $10.0 \mathrm{~g}$ of peptone, $5.0 \mathrm{~g}$ of $\mathrm{NaCl}$ and $3.0 \mathrm{~g}$ of beef powder $\mathrm{L}^{-1}$ )

Activated sludge from a municipal sewage treatment plant $\mathrm{Pt} / \mathrm{C}$ or nitrogen

Mixed community

\section{Shewanella}

Carbon paper oneidensis MR-1

\section{Nanowires \\ observed by SEM - \\ direct transfer \\ $1.57 \mathrm{~W} \mathrm{~m}^{-2}$ \\ direct transfer}

$$
\text { - } \quad 817 \mathrm{~mW} \mathrm{~m}^{-2}
$$

$$
776 \pm 12 \mathrm{~mW} \mathrm{~m}^{-2}
$$
$18 \mathrm{mM}$ lactate substrate
Outer
membrane cytochr ome proteins and
excreted redox mediators
(riboflavin)




\begin{tabular}{|c|c|c|c|c|c|}
\hline Carbon paper & Carbon paper & $\begin{array}{c}\text { Shewanella } \\
\text { oneidensis MR-1 }\end{array}$ & $\begin{array}{l}18 \mathrm{mM} \text { lactate } \\
\text { substrate }\end{array}$ & $\begin{array}{c}\text { Outer } \\
\text { membrane cytochr } \\
\text { ome proteins and } \\
\text { excreted redox } \\
\text { mediators } \\
\text { (riboflavin) }\end{array}$ & $142 \mathrm{~mW} \mathrm{~m}^{-2}$ \\
\hline $\begin{array}{c}\text { Graphene nanosheets } \\
\text { coated onto carbon } \\
\text { paper }\end{array}$ & Carbon paper & $\begin{array}{c}\text { Shewanella } \\
\text { oneidensis MR-1 }\end{array}$ & $\begin{array}{l}18 \text { mM lactate } \\
\text { substrate }\end{array}$ & $\begin{array}{c}\text { Outer } \\
\text { membrane cytochr } \\
\text { ome proteins and } \\
\text { excreted redox } \\
\text { mediators } \\
\text { (riboflavin) }\end{array}$ & $203 \mathrm{~mW} \mathrm{~m}^{-2}$ \\
\hline Carbon paper & Carbon paper & Mixed community & $\begin{array}{c}\text { Anaerobic sludge, } \\
\text { with glucose }\end{array}$ & $\begin{array}{l}\text { Direct electron } \\
\text { transfer }\end{array}$ & $182 \mathrm{~mW} \mathrm{~m}^{-2}$ \\
\hline $\begin{array}{l}\text { Layer by layer } \\
\text { addition of graphene } \\
\text { monolayers onto } \\
\text { carbon paper }\end{array}$ & Carbon paper & Mixed community & $\begin{array}{c}\text { Anaerobic sludge, } \\
\text { with glucose }\end{array}$ & $\begin{array}{l}\text { Direct electron } \\
\text { transfer }\end{array}$ & $368 \mathrm{~mW} \mathrm{~m}^{-2}$ \\
\hline $\begin{array}{c}\mathrm{MnO}_{2} \text { treated graphite } \\
\text { felt }\end{array}$ & Carbon felt & Mixed community & $\begin{array}{c}\text { Sludge and } \\
\text { sediment with } \\
\text { sodium acetate } \\
\text { substrate }\end{array}$ & - & $83 \mathrm{~W} \mathrm{~m}^{-3}$ \\
\hline
\end{tabular}




\begin{tabular}{|c|c|c|c|c|c|}
\hline $\begin{array}{l}\text { Platinum loaded } \\
\text { carbon cloth }\end{array}$ & $\begin{array}{l}\text { carbon-cloth electrode } \\
\text { containing } 0.5 \mathrm{mg} / \mathrm{cm}^{2} \\
\text { of Pt catalyst (E-Tek) }\end{array}$ & Mixed community & $\begin{array}{l}\text { Waste water with } \\
\text { glucose substrate }\end{array}$ & - & $262 \pm 10 \mathrm{~mW} \mathrm{~m}$ \\
\hline $\begin{array}{l}\text { Platinum loaded } \\
\text { carbon paper }\end{array}$ & Carbon paper & $\begin{array}{c}\text { Geobacter } \\
\text { metallireducens }\end{array}$ & Acetate & - & $38 \mathrm{~mW} \mathrm{~m}^{-2}$ \\
\hline $\begin{array}{l}\text { Crumpled graphene } \\
\text { coating on carbon } \\
\text { cloth electrodes }\end{array}$ & Carbon cloth & Anaerobic sludge & Sodium acetate & - & $3300 \mathrm{~mW} \mathrm{~m}^{-2}$ \\
\hline $\begin{array}{l}\text { Carboxyl graphene } \\
\text { coated onto stainless } \\
\text { steel fibre felt }\end{array}$ & Carbon felt & Mixed community & Acetate & - & $2143 \mathrm{~mW} \mathrm{~m}^{-2}$ \\
\hline $\begin{array}{l}\text { Carboxyl graphene } \\
\text { coated onto carbon } \\
\text { cloth }\end{array}$ & Carbon felt & Mixed community & Acetate & - & $1018 \mathrm{~mW} \mathrm{~m}^{-2}$ \\
\hline $\begin{array}{l}\text { Graphene micro- } \\
\text { sheets } \\
\text { electrochemically } \\
\text { exfoliated onto carbon } \\
\text { cloth }\end{array}$ & Graphite rods & Mixed community & $\begin{array}{l}\text { Domestic waste } \\
\text { water-Glucose }\end{array}$ & - & $2850 \mathrm{~mW} \mathrm{~m}^{-2}$ \\
\hline $\begin{array}{l}\text { Graphene oxide } \\
\text { coated onto carbon } \\
\text { cloth }\end{array}$ & $\begin{array}{c}\text { Carbon cloth coated with } \\
\text { Pt catalyst }(20 \% \mathrm{Pt} / \mathrm{C}, \mathrm{E}- \\
\text { Tek) at a loading of } 0.5 \\
\mathrm{mg} / \mathrm{cm}^{2}\end{array}$ & E. coli & $\begin{array}{c}\text { Activated } \\
\text { anaerobic sludge } \\
\text { - sodium acetate }\end{array}$ & - & $1905 \mathrm{~mW} \mathrm{~m}^{-2}$ \\
\hline
\end{tabular}


Graphene oxide

coated onto carbon cloth

Polyaniline/graphene foam coated onto carbon cloth

Polypyrrole/oxidised graphene coated onto graphite felt

$\mathrm{MnO}_{2} /$ functionalised graphene nanosheets

Graphene oxide/ $\mathrm{SnO}_{2}$ composites coated onto graphite

MWCNTs coated onto carbon cloth
Carbon cloth

Carbon cloth

Carbon felt

S. oneidensis

Lactate

Anaerobic sludge

- Acetate

Stainless steel net with wet-proof gas diffusion layers, and a catalyst layer $(86 \mathrm{wt} \%$ activated carbon powder, $12 \mathrm{wt} \%$ PTFE, and $2 \mathrm{wt} \%$ acetylene black powder, containing $5 \mathrm{mg} \mathrm{cm}^{-2}$ $\mathrm{MnO} 2 / \mathrm{GNS}$ catalyst)

\section{Platinum rod}

$$
\text { E. coli }
$$

Glucose

Domestic

Carbon cloth coated with

CNTs or Carbon cloth coated with CNTs and $0.5 \mathrm{mg} \mathrm{cm}^{-2}$ of $\mathrm{Pt}$$$
\text { - Acetate }
$$

Mixed community wastewater Acetate
Electron shuttle pyocyanin

$52.5 \mathrm{~mW} \mathrm{~m}^{-2}$

Mixed community$$
2083 \mathrm{~mW} \mathrm{~m}^{-2}
$$

$$
1326 \mathrm{~mW} \mathrm{~m}^{-2}
$$


catalyst or Carbon cloth coated with CNTs and

$0.5 \mathrm{mg} \mathrm{cm}^{-2}$ of $\mathrm{Pt}$

catalyst and PEM fused

$$
\text { directly }
$$

Graphene $/ \mathrm{TiO}_{2}$ composites coated onto carbon paper

Graphene oxide/CNTs coated onto hydrogel
Carbon paper

Carbon cloth
S. oneidensis

Lactate

Glucose
E. coli
$1060 \mathrm{~mW} \mathrm{~m}^{-2}$

Key: CNTs - carbon nanotubes; MWCNT - multi-walled carbon nanotube; N/A - not available; PBS - phosphate buffer solution. 


\section{Figure 1}

A) Average power outputs of a range of fuel technologies, including both traditional energy sources (i.e. coal and natural gas) and alternative/renewable energy sources. B) Shows the average efficiency range of these fuel sources. Note that MFCs require further and sustained research to compare with other energy sources. Data obtained from [106, 112, 294-296].

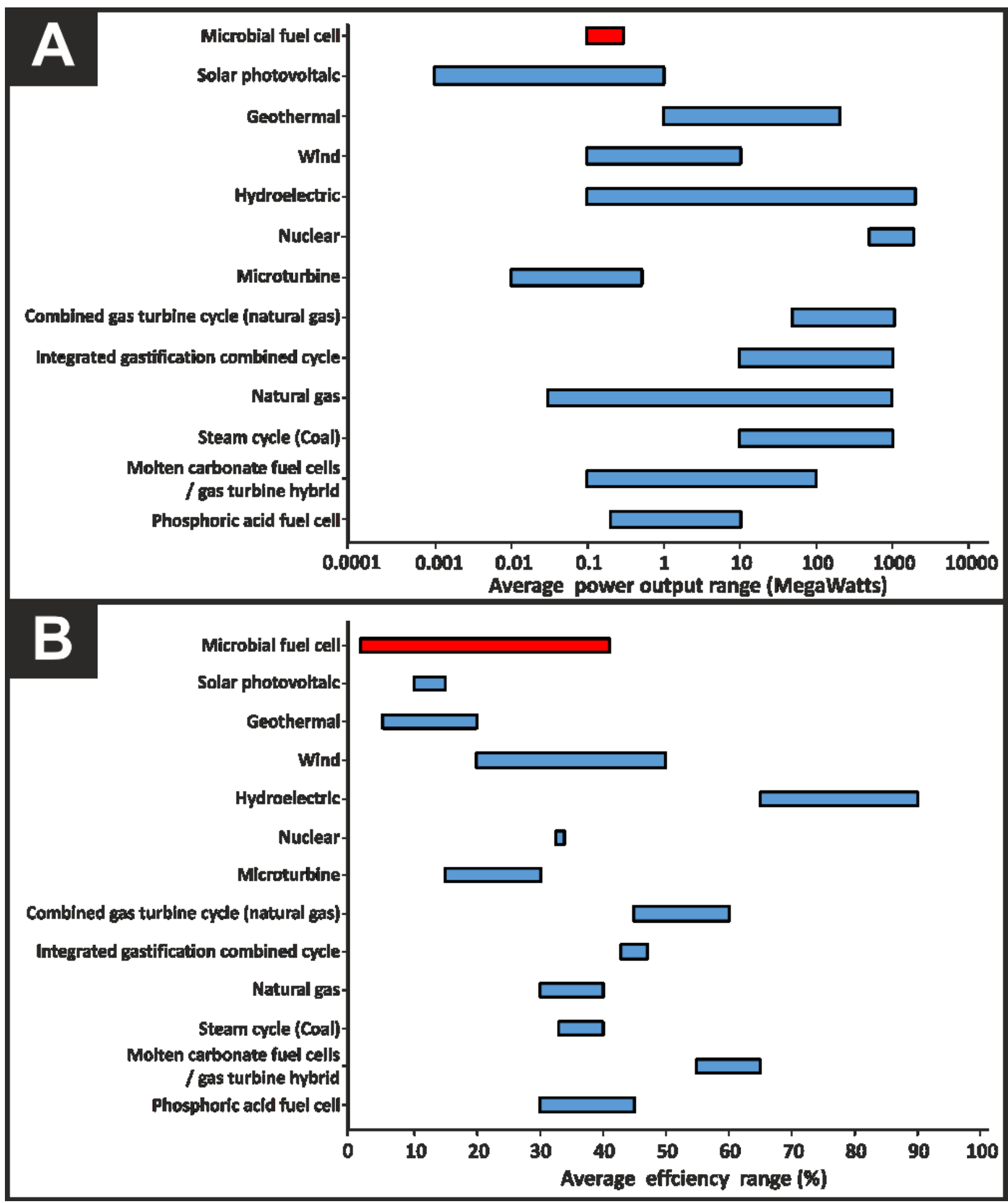




\section{Figure 2}

Schematic of a typically employed two-chamber microbial fuel cell highlighting the various electrochemical and electro-microbiological processes. Figure adapted from reference [1].

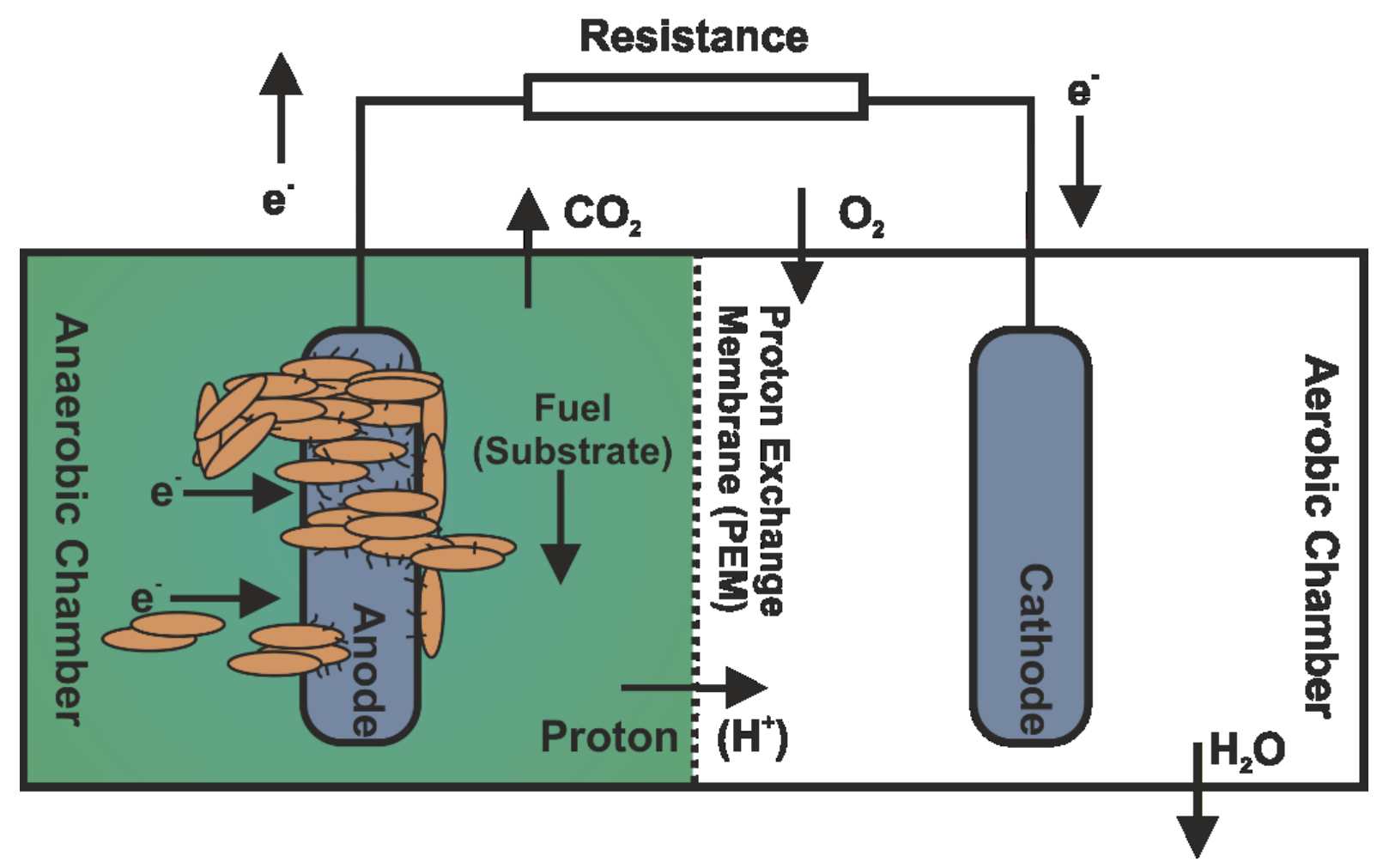




\section{Figure 3}

A schematic depicting a number of ways in which performance of MFC technologies can degrade. Examples here include biofouling (electrode blockage), inactivation of catalysts and excessive growth of bacterial biofilms leading to the production of non-conductive debris. Figure adapted from [106].

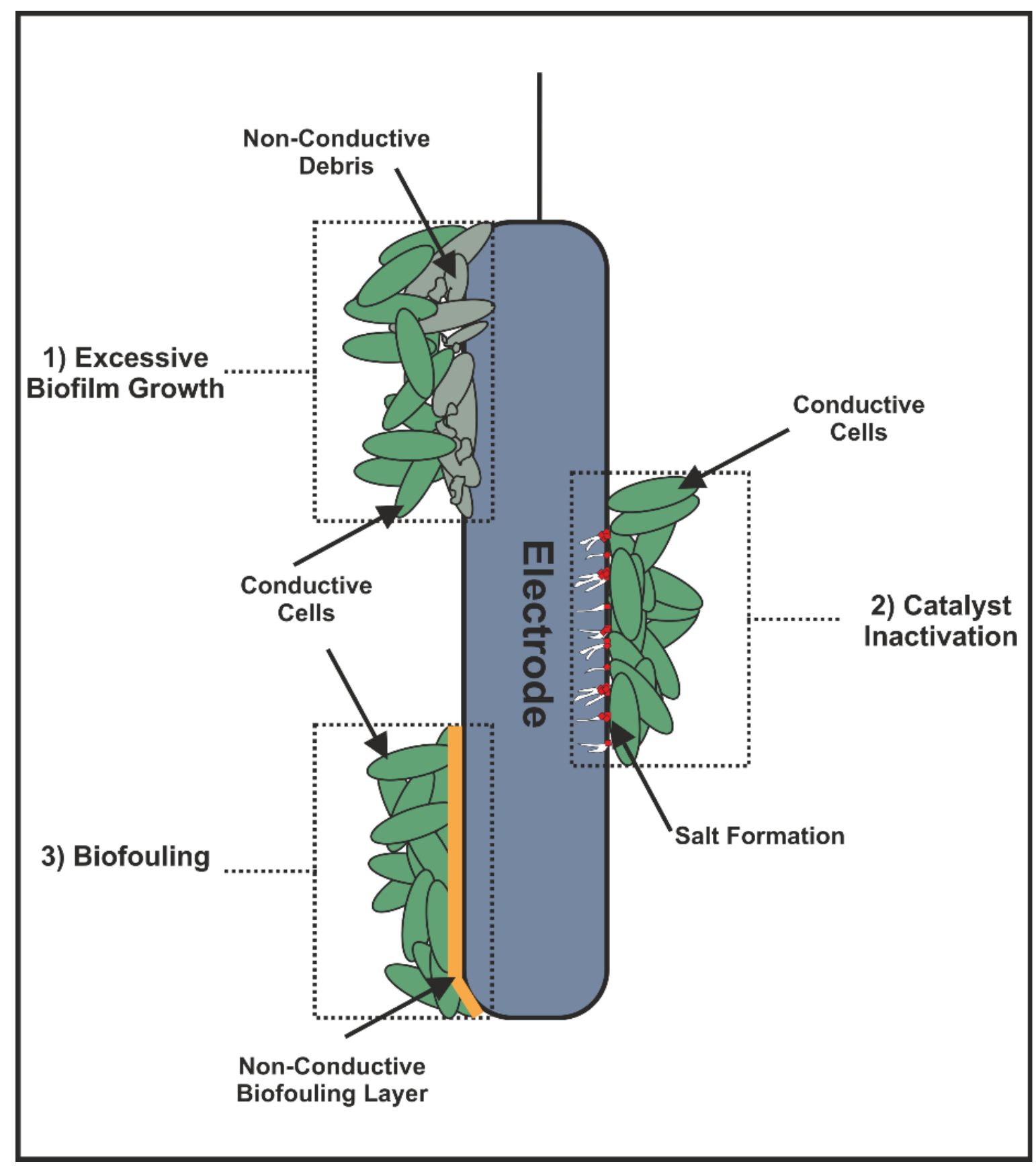




\section{Figure 4}

A) Five allotropes of carbon: (a) graphite (b) diamond (c) $\mathrm{C}_{60}$ buckminsterfullerene (d) singlewalled nanotube (SWCNT), and (e) graphene. These materials are used extensively within microbial fuel cells. Reproduced with permission from [153]. B) SEM showing the abundant coverage of an E.coli biofilm adhered to the surface of a carbon-paste graphite electrode (Figure $5 \mathrm{~B}$ is courtesy of Whitehead et al, MMU, UK).

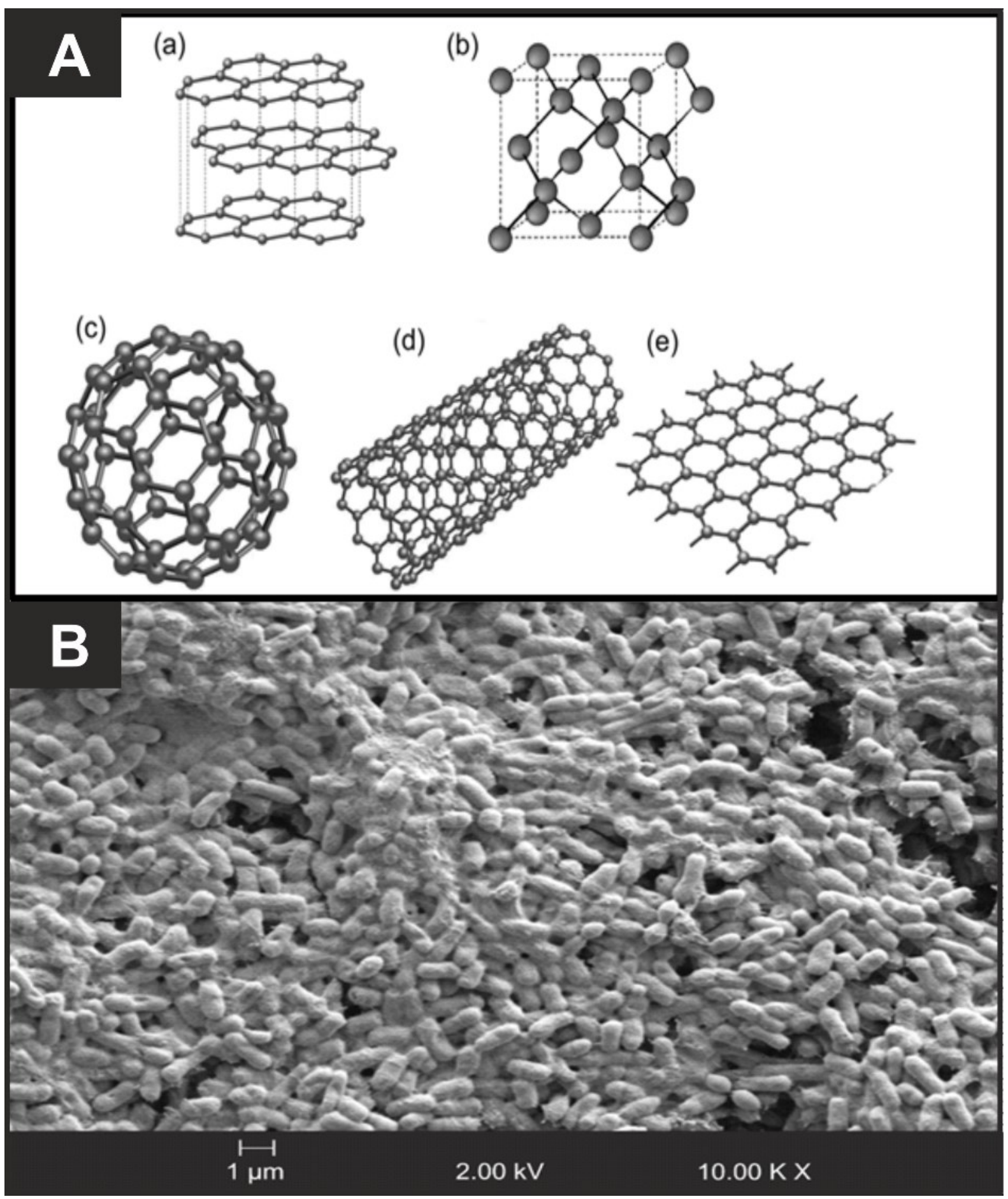




\section{Figure 5}

SEM showing varying morphologies of carbon - based electrodes: (A) carbon fibres in unmodified carbon cloth; (B) regular r-GO sheets deposited on carbon cloth; (C) crumpled rGO particles before being applied onto carbon cloth; and (D) crumpled r-GO particles stacked on carbon cloth. E) The polarisation curves (below the SEM images) show the electricity generation from the carbon - based electrodes, indicating that the reduced graphene oxide particles produced the highest power density, possibly due to the higher electrode surface area as observed in the SEM images (D). Figure adapted from reference [172].

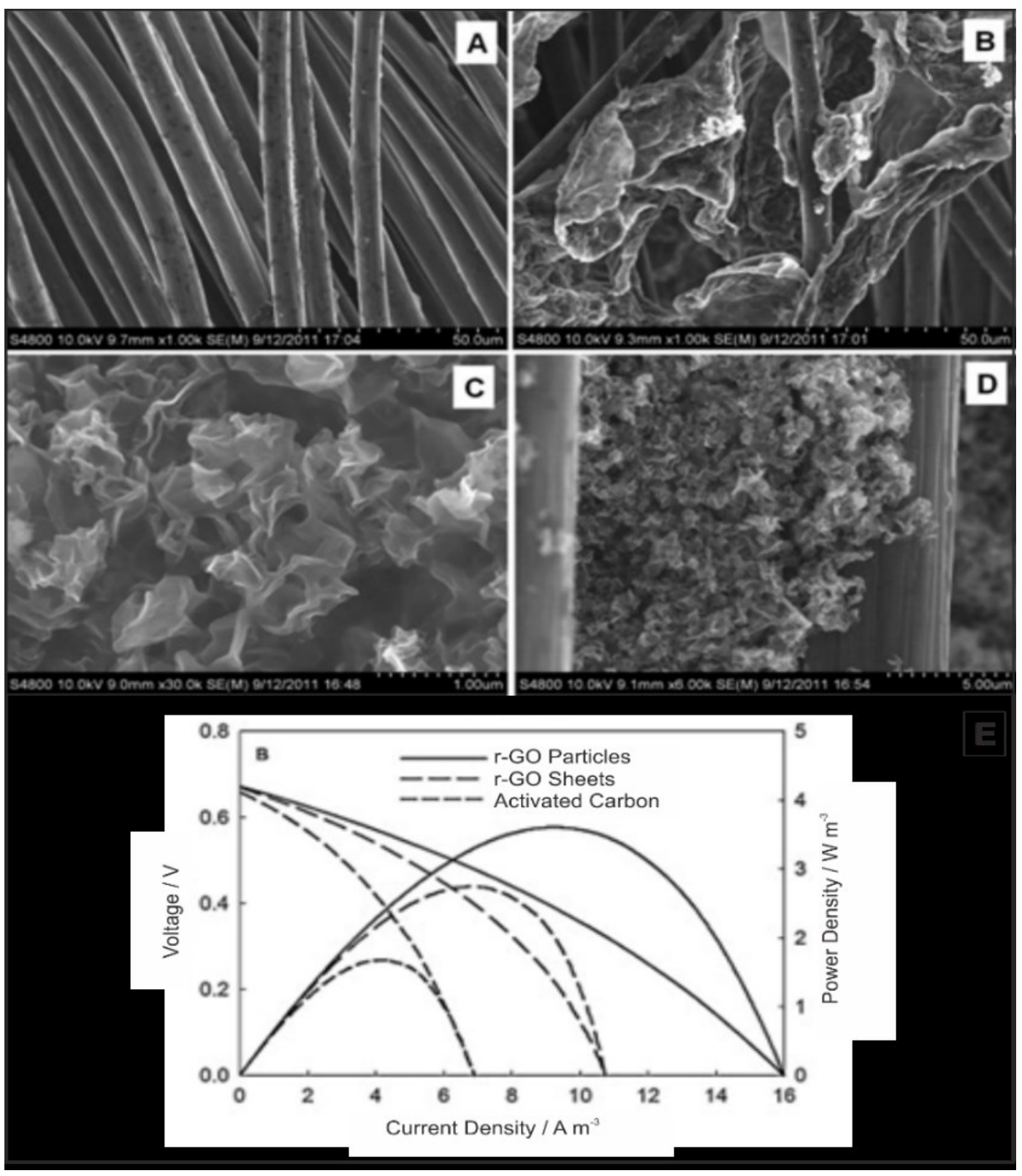




\section{Figure 6}

SEM showing A) 3D graphene macroporous scaffold fabricated via chemical vapour deposition, B) monolayer graphene, C) morphology of biofilm adhered to the 3D graphene macroporous scaffold anode and E) morphology of biofilm adhered to monolayer graphene anode. Optical profilometry images of both the 3D graphene macroporous and monolayer anodes with biofilms adhered are shown, D) and F) respectively, this allowed the biofilm thickness to be quantified before SEM was utilised to show morphological differences - C) and E). Figure adapted from [174].

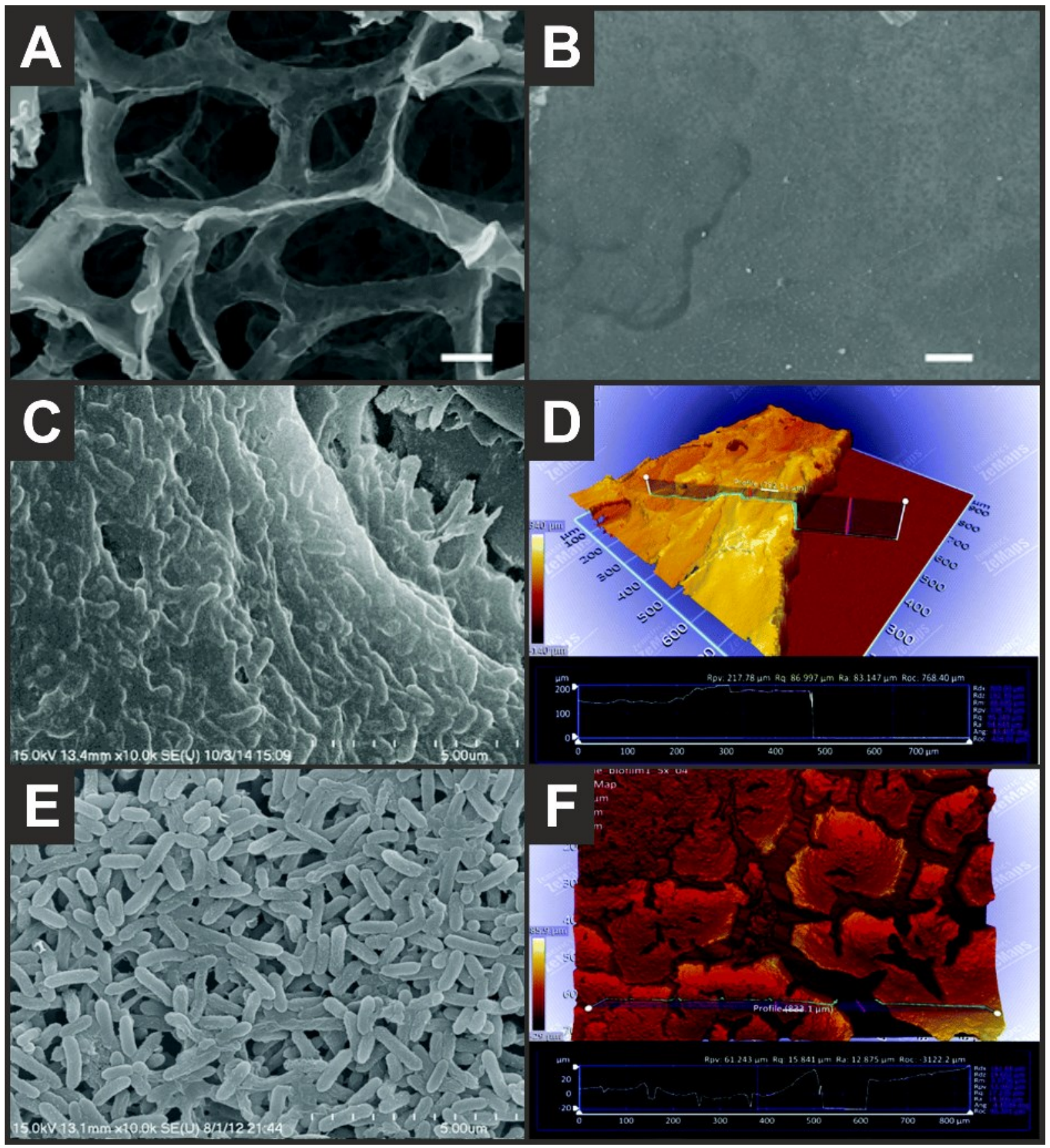




\section{Figure 7}

The MFC with the largest power output reported to date. A) A plot of power density versus current density, B) A plot of current density against voltage. Varying anodes were utilised throughout this study: control, 2D single layer graphene, and 3D graphene macroporous scaffold; unless specified, all data collected at $18 \mu \mathrm{L} \mathrm{min}^{-1}$ (via flow cell set-up). Reproduced with permission from [174].

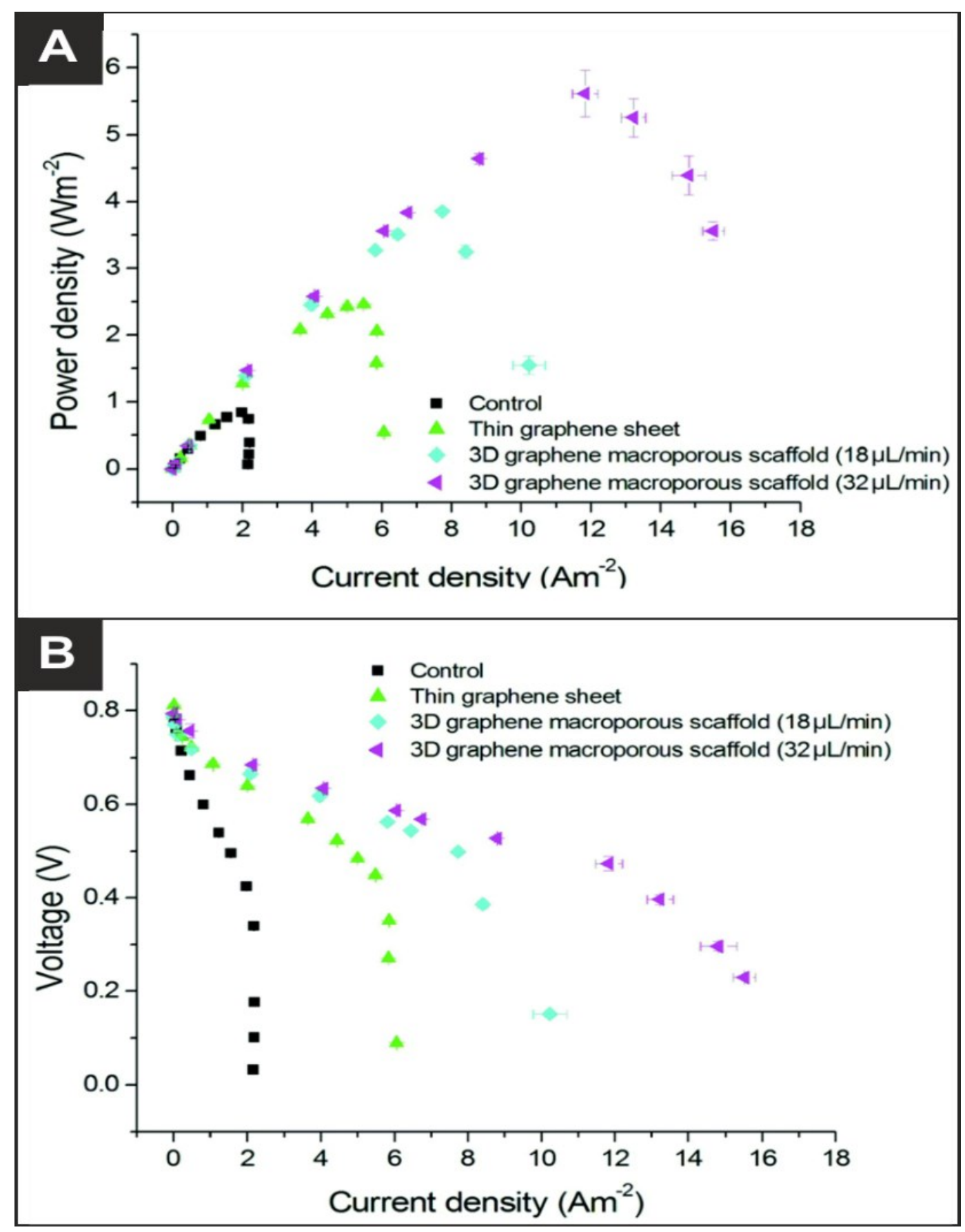




\section{Figure 8}

Comparison of a selection of metal electrodes utilised in MFC configurations compared to a graphite control. A) Electrochemical performance, with the red columns showing average maximum current densities achieved and the blue columns showing the mean values of the slopes of the turnover cyclic voltammograms. B) Correlation of the electro-catalytic current density against biofilm thickness (as determined via confocal laser scanning microscopy). Figure adapted from [189].

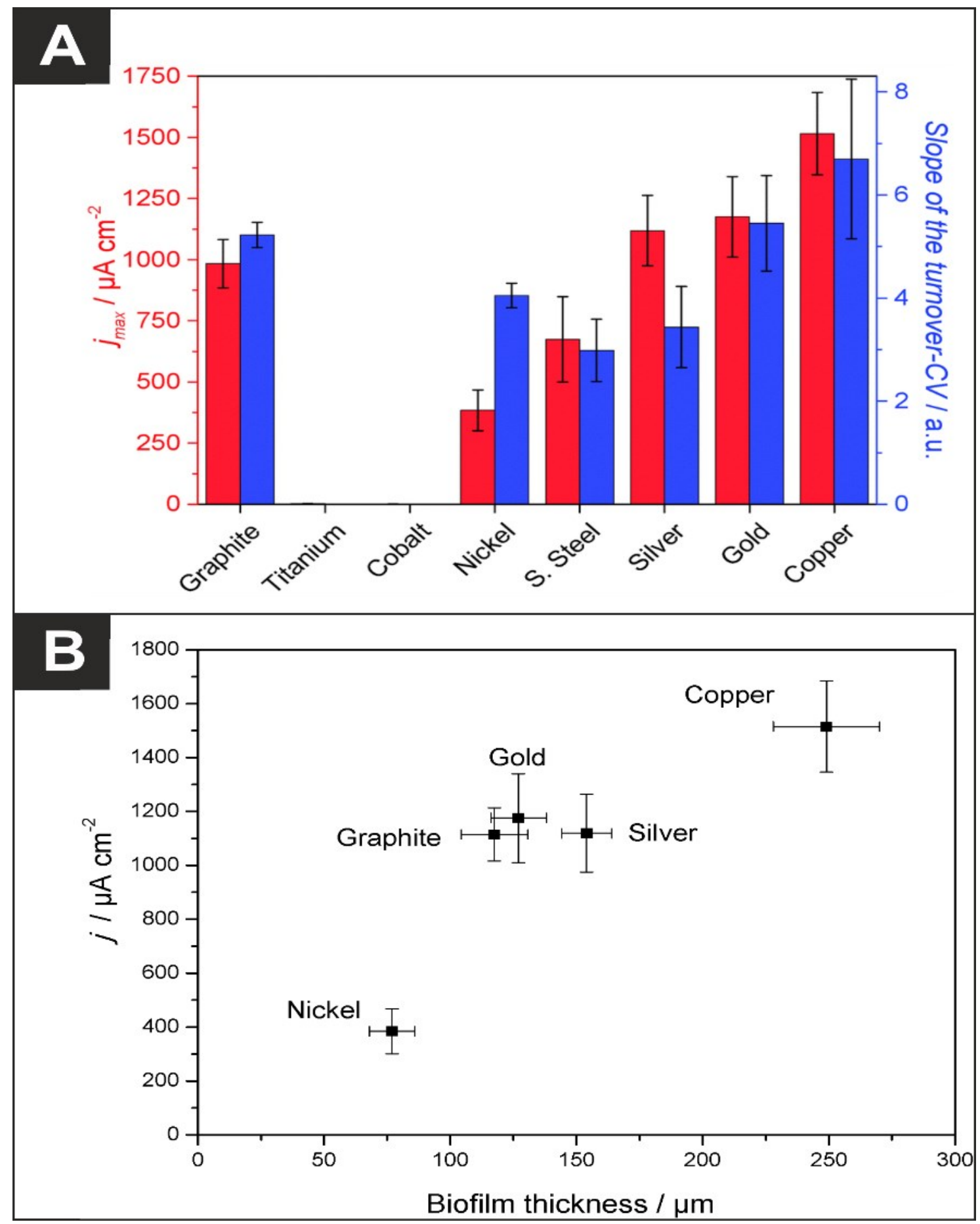




\section{Figure 9}

Three methods of electron transfer demonstrated by exoelectrogenic bacteria, including; direct electron transfer - conductive pili denoted within the literature as nanowires and redox-active proteins, and indirect electron transfer by electron shuttles. Reproduced with permission from [200].

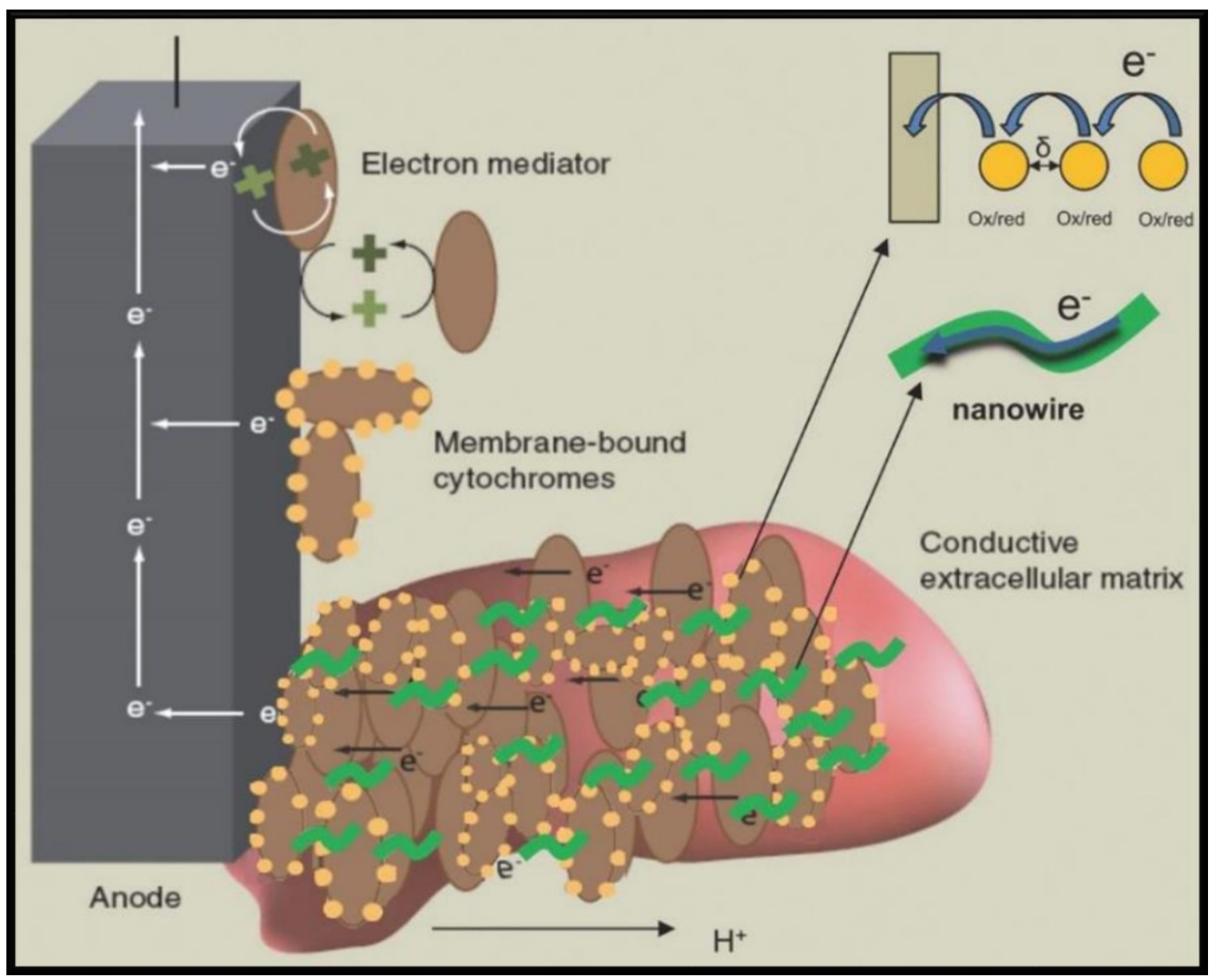




\section{Figure 10}

A) SEM showing the difference in morphology of flagella and pili on the surface of E. coli. Due to this distinct difference in properties, we propose the terms "micro-nanowires" and "macro-nanowires" in order to describe pili and flagella, respectively, in terms of electron transfer properties in MFC configurations. Section A image, courtesy of Whitehead et al, MMU, UK. B) Transmission electron microscopy showing G. sulfurreducens strain GUP, (top part of the image), expressing abundant micro-nanowires. This allows the bacteria to reduce metals, such as iron oxide, and donate electrons to the anode in a MFC set-up. Section B, adapted from [208].

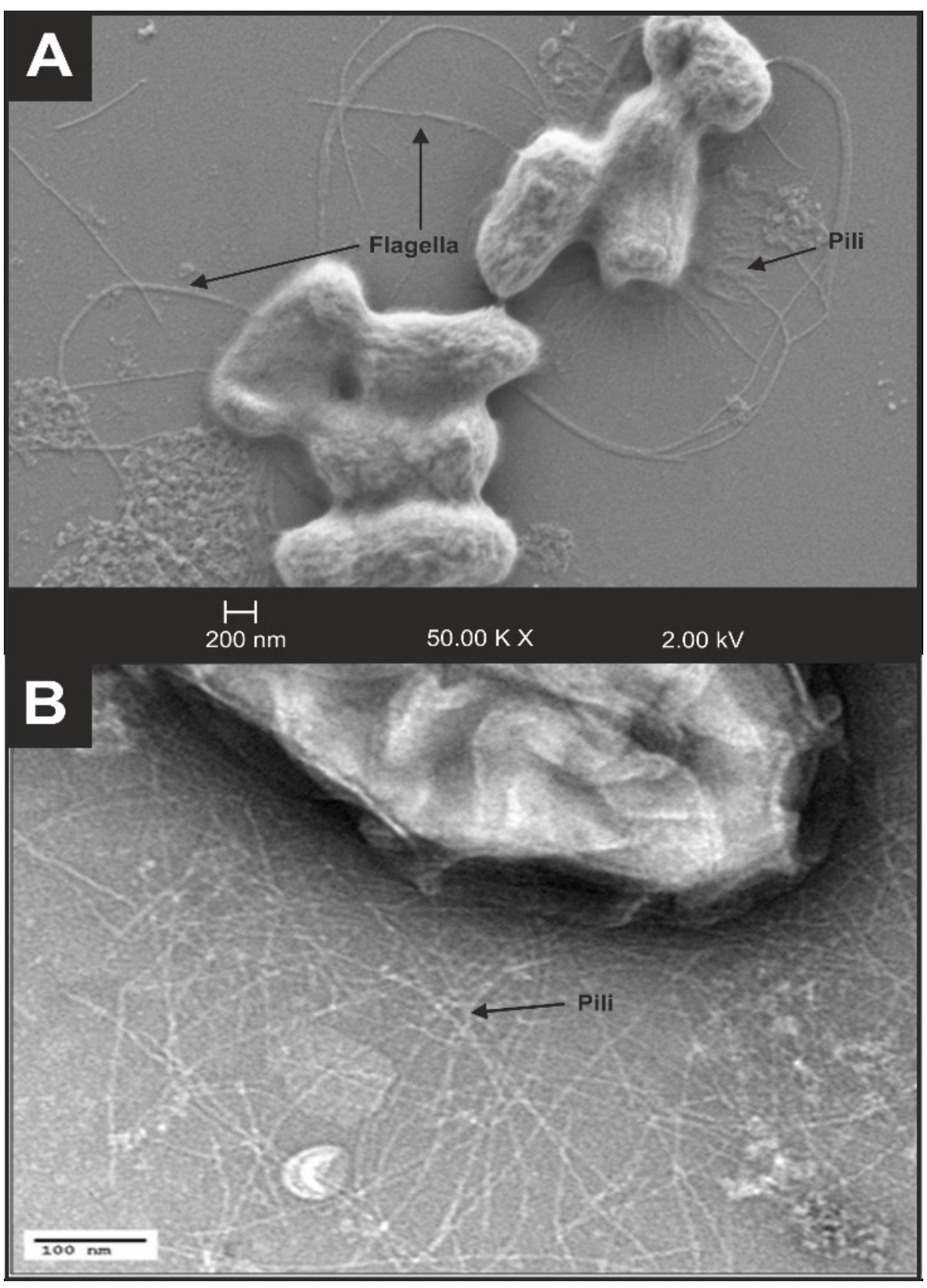




\section{Figure 11}

Schematic depicting a range of exogenous and endogenous redox mediators, capable of partaking in electron transfer. Original image adapted from [297].

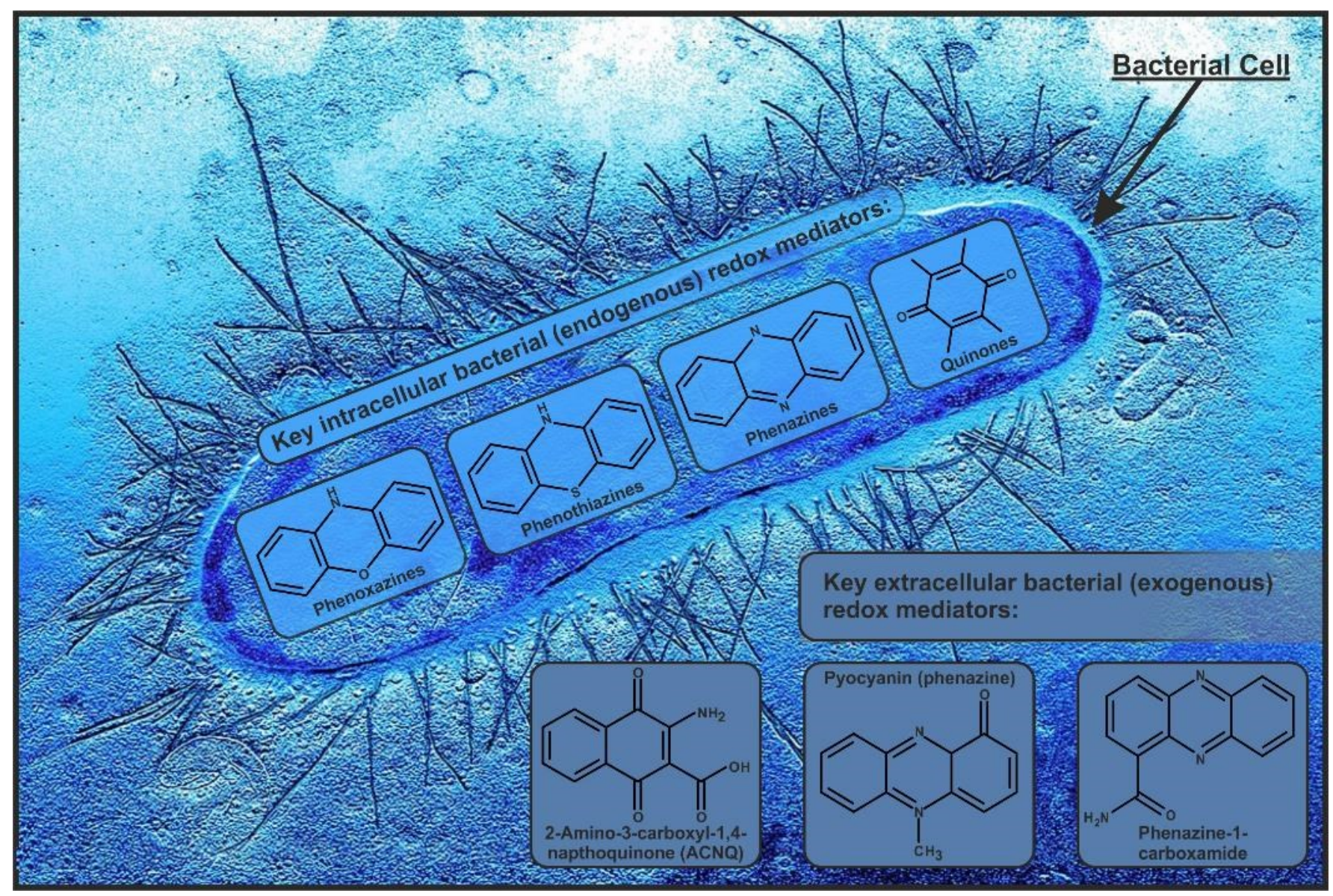

